\section{U.S. DEPARTMENT OF ENERCY}

\section{Office of}

ENERGY EFFICIENCY \& RENEWABLE ENERGY
Lab Home Testing of Residential Isolation Space Control to Minimize Infectious Disease Transmission in Existing Single-Family Homes

May 2021 


\section{Disclaimer}

This work was prepared as an account of work sponsored by an agency of the United States Government. Neither the United States Government nor any agency thereof, nor any of their employees, nor any of their contractors, subcontractors or their employees, makes any warranty, express or implied, or assumes any legal liability or responsibility for the accuracy, completeness, or any third party's use or the results of such use of any information, apparatus, product, or process disclosed, or represents that its use would not infringe privately owned rights. Reference herein to any specific commercial product, process, or service by trade name, trademark, manufacturer, or otherwise, does not necessarily constitute or imply its endorsement, recommendation, or favoring by the United States Government or any agency thereof or its contractors or subcontractors. The views and opinions of authors expressed herein do not necessarily state or reflect those of the United States Government or any agency thereof, its contractors or subcontractors.

Available electronically at Office of Scientific and Technical Information website (osti.gov)

Available for a processing fee to U.S. Department of Energy

and its contractors, in paper, from:

U.S. Department of Energy

Office of Scientific and Technical Information

P.O. Box 62

Oak Ridge, TN 37831-0062

OSTI osti.gov

Phone: 865.576 .8401

Fax: 865.576.5728

Email: reports@osti.gov

Available for sale to the public, in paper, from:

U.S. Department of Commerce

National Technical Information Service

5301 Shawnee Road

Alexandria, VA 22312

NTIS ntis.gov

Phone: 800.553 .6847 or 703.605 .6000

Fax: 703.605.6900

Email: orders@ntis.gov 


\title{
Lab Home Testing of Residential Isolation Space Control to Minimize Infectious Disease Transmission in Existing Single-Family Homes
}

\author{
Prepared by: \\ Tanvir Khan, Charles Withers, Nicholas Bonilla, and Eric Martin \\ FSEC Energy Research Center \\ Prepared for: \\ Building Technologies Office \\ Office of Energy Efficiency and Renewable Energy \\ U.S. Department of Energy
}

May 2021

NREL Technical Monitor: Conor Dennehy 


\section{Acknowledgments}

This report was funded by the Residential Buildings Integration program within the U.S. Department of Energy, Office of Energy Efficiency and Renewable Energy, Building Technologies Office

\section{Table of Contents}

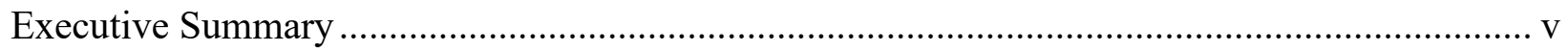

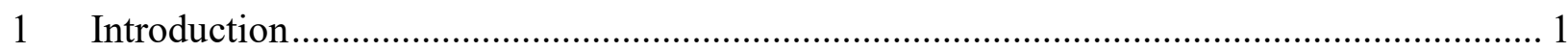

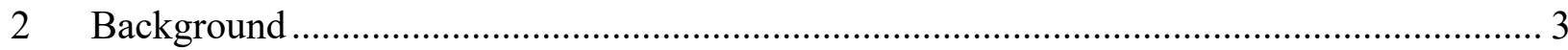

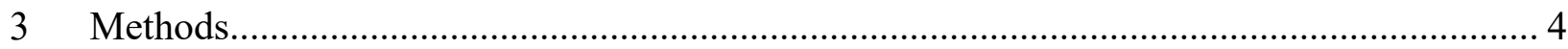

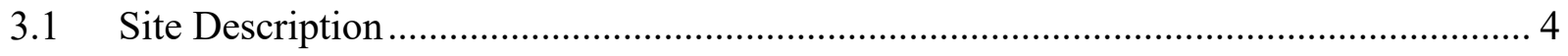

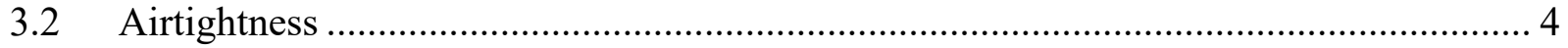

3.3 Airflow Measurements ............................................................................. 5

3.4 Pressure Differential, Temperature, and Wind Monitoring ....................................... 5

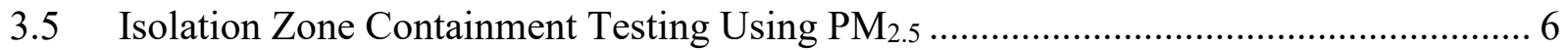

3.6 Isolation Zone Containment Testing Using Tracer Gas............................................ 7

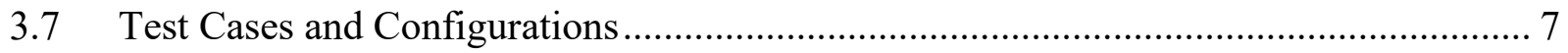

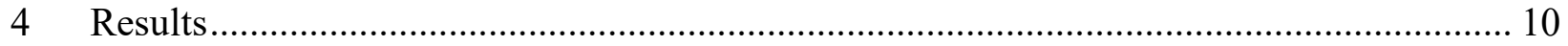

4.1 Airflow Characteristics and Building Airtightness ........................................... 10

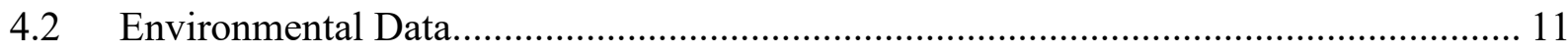

$4.3 \quad$ Best and Worst Containment Test Cases .......................................................... 13

4.3.1 Examples of Four Best Containment Strategies ........................................... 15

4.3.2 Examples of Three Weak Containment Strategies ........................................... 18

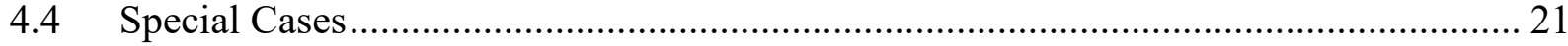

4.4.1 Effect of Opening/Closing Isolation Zone Door............................................. 21

4.4.2 Effect of Using Kitchen Range Hood in the Main Zone ..................................... 22

5 Recommendations for Strong Isolation Zone Containment.......................................... 24

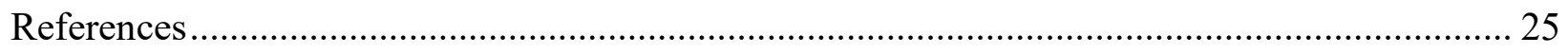

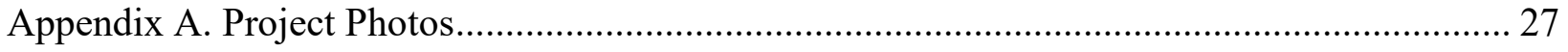


Lab Home Testing of Residential Isolation Space Control to Minimize Infectious Disease Transmission in

\section{Executive Summary}

Existing evidence strongly suggests that viral infectious diseases can be transmitted via an airborne route across distances in indoor environments. Accordingly, the risk of airborne transmission within homes should be managed. The public health emergency associated with SARS-CoV-2 makes controlling airborne transmission of respired viruses in indoor environments critical, especially in poorly ventilated indoor environments. The effectiveness of engineering interventions requiring minor efforts that create a negative-pressure isolation zone (IZ) for a contagious person has yet to be tested for existing residential homes. To mitigate the risk of airborne virus transmission and maximize health protection for the population in existing single-family homes, this report investigates the relative effectiveness of several control strategies. Although very high-efficiency MERV filtration, high ventilation rates, and other controls can help be effective, most occupants are not likely to have the time or means for advanced measures found in hospitals. This project focuses on relatively simple efforts that utilize existing or easy to acquire materials and straightforward processes.

The risk of transmission of a contagious airborne virus can be reduced by isolating a sick person in a depressurized IZ of a single-family home. Within this report, the remaining occupied part of the house outside the IZ is referred to as the main zone (MZ). Further protection can come from bringing outside air into the $\mathrm{MZ}$ using an existing mechanical ventilation system or even a lowcost window fan. This increases ventilation and dilution of pollutants and helps maintain positive pressure with reference to the IZ.

In our test facility, which is a single-family manufactured home, various controls were implemented under various operating conditions. A total of 17 cases were tested, with test conditions summarized in Table ES-1. These strategies were designed based on various heating, ventilating, and air-conditioning (HVAC) operating scenarios, intervention measures, and utilization of exhaust or window fans for pressure control. Interventions involved efforts like closing the IZ door and/or sealing IZ supply air grilles. The primary metric used in this project to evaluate potential containment effectiveness is the "IZ with reference to (w.r.t.) MZ" pressure difference. ASHRAE 170 standard requires a hospital isolation room pressure differential of at least -2.5 $\mathrm{Pa}$ w.r.t. adjacent zones. This pressure differential requirement was the primary basis of comparison. The use of generated particulate matter was a supplementary means of observing containment.

To test the potential effectiveness of IZ containment, fine particulate matter $\left(\mathrm{PM}_{2.5}\right)$ was generated from an essential-oil-based diffuser, and tracer gas was injected in the IZ followed by real-time monitoring of the particulate matter and tracer gas transfer from IZ to MZ. Combining the data from pressure differential monitoring and observed concentrations of $\mathrm{PM}_{2.5}$ and tracer gas across the zones, the potential effectiveness and weakness of several cases were demonstrated. 
Lab Home Testing of Residential Isolation Space Control to Minimize Infectious Disease Transmission in Existing Single-Family Homes

Table ES-1 Test Case Configurations (Highlighted Rows Achieved Best IZ Containment)

\begin{tabular}{|c|c|c|c|c|c|c|c|}
\hline $\begin{array}{c}\text { Case } \\
\#\end{array}$ & $\begin{array}{l}\text { IZ Door } \\
\text { State }\end{array}$ & $\begin{array}{c}\text { IZ Bath } \\
\text { Exhaust } \\
\text { Fan }\end{array}$ & $\begin{array}{l}\text { Window } \\
\text { Fan }\end{array}$ & $\begin{array}{l}\text { IZ Window(s) } \\
\text { State }\end{array}$ & $\begin{array}{c}\text { MZ } \\
\text { Window(s) } \\
\text { State }\end{array}$ & $\begin{array}{l}\text { Central } \\
\text { Heating/ } \\
\text { Coolings }\end{array}$ & $\begin{array}{l}\text { IZ Supply } \\
\text { Grilles }\end{array}$ \\
\hline 1 & Open & Off & No & Closed & Closed & On & Open \\
\hline 2 & Open & On & No & Closed & Closed & On & Open \\
\hline 3 & Closed & Off & No & Closed & Closed & On & Closed \\
\hline 4 & Closed & Off & $\begin{array}{l}\text { In } I Z \text { as } \\
\text { exhaust }\end{array}$ & Closed & Closed & On & Closed \\
\hline 5 & Closed & On & No & Closed & Closed & On & Closed \\
\hline 6 & Closed & On & $\begin{array}{l}\text { In } \mathrm{MZ} \text { as } \\
\text { supply }\end{array}$ & Closed & Closed & On & Closed \\
\hline 7 & Closed & Off & $\begin{array}{c}\text { In MZ as } \\
\text { supply }\end{array}$ & Closed & Closed & On & Closed \\
\hline 8 & Closed & On & No & Open (1) & Closed & Off & Closed \\
\hline 9 & Closed & On (low) & No & Closed & Closed & On & Closed \\
\hline 10 & \multicolumn{7}{|c|}{$\begin{array}{c}\text { Monitoring IZ containment during } \mathrm{IZ} \text { to } \mathrm{MZ} \text { door opening/closing } \\
\text { under conditions for Case } 5\end{array}$} \\
\hline 11 & Closed & On & No & Closed & Closed & On & Open \\
\hline 12 & Closed & Off & $\begin{array}{l}\text { In } I Z \text { as } \\
\text { exhaust }\end{array}$ & Closed & Closed & On & Open \\
\hline 13 & Closed & Off & No & Closed & Open (2) & Off & Closed \\
\hline 14 & Closed & On & No & Closed & Closed & On & $\begin{array}{c}\text { Open } \\
\text { (partial) }\end{array}$ \\
\hline 15 & Closed & Off & No & Open (2) & Closed & Off & Closed \\
\hline $16^{*}$ & Closed & Off & Off & Closed & Closed & Off & Closed \\
\hline $17^{* *}$ & Closed & Off & Off & Closed & Closed & On & Closed \\
\hline
\end{tabular}

Note: All tests with IZ bath exhaust fan "On" were conducted at a high fan speed setting unless otherwise specified. The number in parentheses for window state denotes the number of windows open during the test in the $\mathrm{IZ}$ and/or MZ.

SHVAC fan ON Continuous

*Use of kitchen range hood in the MZ simulated using a duct blaster (flow: $100 \mathrm{CFM}$, duration: 30 minutes).

$* *$ A portable room air conditioner with exhaust to outside installed in one of the IZ windows.

Containment requires eliminating as many air pathways between the IZ and $\mathrm{MZ}$ as is practical. This involves keeping doors between IZ and MZ closed and blocking IZ supply air grilles. Making the IZ more airtight provides the benefit of requiring less mechanically induced air to maintain negative IZ pressure. Four cases highlighted in Table ES-1 were identified as having the potential for strong containment. These cases exhibited adequate depressurization in the IZ (-2.7 to -7.0 Pa w.r.t. MZ), meeting and/or exceeding the threshold of $-2.5 \mathrm{~Pa}$. For Cases 4 and 5, depressurization was achieved using a low-cost portable exhaust window fan (minimum airflow of 300 cubic feet per minute [CFM]) and an IZ bathroom exhaust fan (which required in-situ minimum airflow of $100 \mathrm{CFM}$ ). For Case 6 , the window fan is used as a supply fan to create pressurization in the $\mathrm{MZ}$ by bringing outside air into $\mathrm{MZ}$, resulting in net negative pressurization 
in the IZ w.r.t MZ. For these effective cases, the MZ to IZ door and all IZ windows remained closed at all times while all IZ supply grilles were sealed off. One major drawback to blocking the IZ supply grilles is that the IZ thermal conditions are likely to become more uncomfortable for the ill isolated person. Therefore, a room space heater or room air conditioner may be needed in the IZ. One experiment, Case 17 in Table ES-1, demonstrated that a portable room air conditioner with process air exhausted to the outdoors could help maintain comfort and also be used to maintain depressurization as long as it was in operation.

Although maintaining the IZ door closed was critical, occasional opening/closing the door for practical purposes such as tending to the sick person did not compromise the containment potential of the IZ, as demonstrated by $\mathrm{PM}_{2.5}$ tests.

Our results indicate that creating an IZ in an existing single-family house need not be complicated. A low-cost $\$ 32$ window fan and simple occupant efforts can be used for potentially effective pressure containment. There may, however, be the need for supplemental IZ space conditioning, which could cost $\$ 75$ for electric space heating and about $\$ 300-\$ 600$ for a room air conditioner. Also, although it is expected that containment is only needed for a short-term period of less than a month, situations requiring longer-term containment should ensure that potential for moisture-related durability concerns is minimized. Such concerns arise when outdoor dew points are high (exceeding $72^{\circ} \mathrm{F}$ ), and due to the long-term infiltration of the humid air that results from space depressurization. In such cases, space-cooling set points should not be set below the outdoor air dew point. This is especially important in homes with vaporimpermeable wall and/or floor coverings, such as vinyl wallpaper. 
Lab Home Testing of Residential Isolation Space Control to Minimize Infectious Disease Transmission in Existing Single-Family Homes

\section{Introduction}

Of the three respiratory virus transmission pathways (i.e., through direct close contact, contact between people and with contaminated surfaces known as fomite, and airborne inhalation) (Morawska et al. 2020), aerosol-based transmission is of particular importance in the context of influenza viruses, the common-cold rhinoviruses, and the novel SARS-CoV-2, especially in the indoor environment (Allen and Marr 2020; Garcia de Abajo et al. 2020; Miller et al. 2020; Morawska and Chao 2020; Morawska et al. 2020). The term "airborne" refers to any transmission that occurs outside of close contacts. During breathing, speaking, sneezing, and coughing, infected individuals exhale both virus-laden droplets $(>5$ to $10 \mu \mathrm{m})$ and aerosols $(<5$ $\mu \mathrm{m})$ (Prather et al. 2020a; Allen and Marr 2020). Viruses in aerosols can remain airborne for hours, and be inhaled deep into the lungs (Prather et al. 2020b; Asadi et al. 2020). In limited sampling in health care settings, the available data suggest the majority of SARS-CoV-2 tend to be associated with aerosols in the size range of 1 to $4 \mu \mathrm{m}$ (Chia et al. 2020; Liu et al. 2020). Aerosols containing infectious viruses can travel more than $2 \mathrm{~m}$ and accumulate in poorly ventilated indoor air (Miller et al. 2020; Lednicky et al. 2020).

Existing case studies and evidence strongly suggest that viral infectious diseases can be transmitted via aerosols across distances in indoor environments (WHO 2009). For SARS-CoV2, sharing indoor space in the presence of infected individuals has been confirmed as a risk factor in the transmission of COVID-19 (Allen and Marr 2020; Miller et al. 2020). ASHRAE acknowledged the airborne route for transmission from person to person indoors and recommended ventilation control measures accordingly (ASHRAE 2020), stating that "transmission of SARS-CoV-2 through the air is sufficiently likely that airborne exposure to the virus should be controlled. Changes to building operations, including the operation of heating, ventilating, and air-conditioning systems, can reduce airborne exposures.” To mitigate the risk for the population in indoor environments, appropriate control strategies can be utilized. A majority of these control strategies are engineering-level controls, including mechanical ventilation, air cleaning and disinfection, and ultraviolet germicidal irradiation disinfection applied to public or commercial buildings.

In the United States, most health-care facilities use negative-pressure airborne infection isolation rooms (AIIRs) for patients with airborne transmissible infections (Miller et al. 2017). To ensure virus containment, the pressure in AIIRs with reference to an external zone such as a hospital corridor is recommended to be $-2.5 \mathrm{~Pa}$ (ASHRAE Standard 170 2013). To reduce the health risks for airborne transmission in residential buildings, including single-family homes and apartments, practical measures such as segregating infected individuals, opening windows and doors, and using portable air-cleaning devices are commonplace (Morawska et al. 2020). However, the concept of utilizing negative-pressure or depressurization while creating an isolation zone (IZ) or room in an existing single-family home as a practical approach to protect the rest of the people in the home has not been systematically studied and reported, to our knowledge. Using existing spot ventilation such as a bathroom exhaust fan and/or commercially available low-cost window 
fans could be used to create a pressure differential across rooms. Such measures may substantially reduce virus concentrations in the indoor air relative to the base case of no intervention, resulting in lower risk of airborne transmission at a relatively low cost and without any major modifications to the existing heating, ventilating, and air-conditioning (HVAC) system.

ASHRAE Standard 170 addresses commercial health-care facilities and contains wellestablished principles of isolation disease control. This standard was used as guidance in developing practical and attainable recommendations for residential single-family homes. Given limitations of specific homes and occupants, it is recognized that a residential IZ may not offer the same confidence in protection as Standard 170, but should considerably reduce exposure to healthy occupants.

The issue: A situation can occur when someone in the home has a confirmed or suspected infection or is required to be quarantined. If they are distributing viruses in the air, how can the rest of the occupants in the home avoid becoming sick?

The overarching objective of the study: to systematically test the effectiveness of various strategies to mitigate potential airborne transmission of infectious aerosols in a manufactured single-family laboratory house under various HVAC operating scenarios, intervention measures, and utilization of exhaust or window fans for pressure control. 
Lab Home Testing of Residential Isolation Space Control to Minimize Infectious Disease Transmission in Existing Single-Family Homes

\section{Background}

In many single-family detached homes built in the last 40 years (and some built prior), there is a master bedroom with an attached bathroom that has an exhaust fan ducted to the outside. Typically, this bathroom has a sole entry point from the master bedroom. Closing the door to the master bedroom from the main body of the house and running the exhaust fan has the potential to maintain the master suite zone at a negative pressure with reference to (w.r.t.) adjacent rooms when central heating or cooling is not on. Further effort to block gaps around the closed door between the isolation room and the main body of the building would improve control of negative pressure in the isolation room relative to adjacent spaces. If the building is reasonably airtight and the exhaust fan has enough airflow, zone isolation from the master suite exhaust fan with a couple of additional room modifications may provide adequate air control. Some homes have central return air ducts, ducted returns, or passive return air transfers in bedrooms. Ducted and passive return air pathways in the isolation room must be sealed off to block air transfer from the isolation room into the rest of the home during heating, cooling, or central air circulation operation. Supply from the central system into the isolation space may exceed the exhaust airflow, resulting in periods of pressurization instead of desired depressurization. It is imperative that the central system supply grille airflow into the isolation space be reduced such that adequate depressurization w.r.t. the main body occurs. This is best accomplished by the application of tape and paper or plastic over as much of the grille as necessary. A portable room air conditioner, space heater, or floor fan may be needed to improve comfort in the isolation space.

The main body of the home will operate at slightly negative pressure w.r.t. outside if the isolation room return pathway is sealed and supply air vents are left unsealed. Positively pressurizing the main body w.r.t. outside offers further protection, and may be accomplished by increasing supply ventilation of the main body of the house. This can be as simple as using a portable fan if the home does not have an existing operable supply mechanical ventilation system. Ventilation can be increased by using a portable floor or through-window/wall fan placed into an open window or door, positioned to supply outdoor air into the home. This should also increase the pressure difference between the main body of the home and the isolated room. Closing doors and dedicated returns from the master suite will not necessarily close off all potential paths of unintentional airflow from a master bedroom to the main space. However, by creating a pressure differential via the exhaust fan or fan in the window, any such pathways should result in air moving from the main zone (MZ) to the master suite instead of the reverse. The potentially contaminated air should remain isolated within the master suite and be exhausted or exfiltrated to the outside. Uninfected persons at greater health risk will benefit from increased outdoor ventilation to the main body of the home, or even a specific bedroom, as ventilation dilutes pollutants and helps isolate them in a positive pressure space relative to other spaces. 
Lab Home Testing of Residential Isolation Space Control to Minimize Infectious Disease Transmission in Existing Single-Family Homes

\section{Methods}

\subsection{Site Description}

To help determine the effectiveness of containment of airborne contaminants within a home, FSEC's Manufacturing Housing Laboratory (MHLab) was used. Located in Cocoa, Florida, the MHLab is a $1,620-\mathrm{ft}^{2}$ manufactured home with three bedrooms and two bathrooms. It has an unvented and unconditioned crawl space, R19 floor insulation, vented attic with R30 insulation on the ceiling, wood frame wall construction with R19 insulation, double-pane low-e windows. The MHLab has a house airtightness of about 5 air changes per hour with the house at 0.20 in WC (50 Pa of pressure) w.r.t. outdoors (5 ACH50). The effectiveness of control strategies will depend upon house and zone tightness. Older leakier homes would require more ventilation airflow for containment. The floorplan of MHLab is shown in Figure 1. For each test, the master suite served as the IZ.

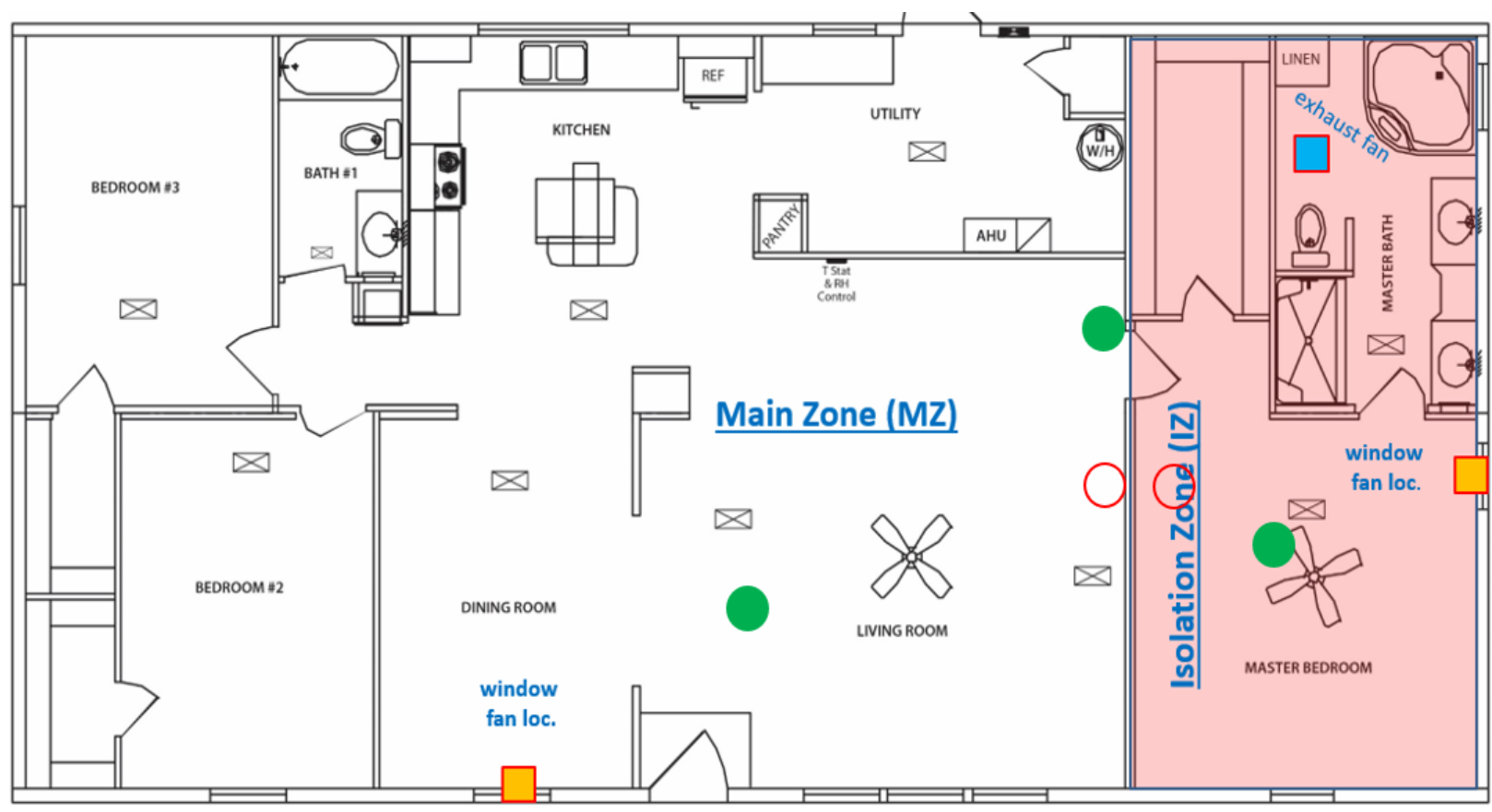

Figure 1. FSEC Manufactured Housing Laboratory floorplan. Green dots denote the locations of $\mathrm{PM}_{2.5}$ monitors, and red circles denote the locations of tracer gas $\left(\mathrm{SF}_{6}\right)$ measurements.

Appendix A includes photos of the experimental setup and equipment.

\subsection{Airtightness}

To determine the airtightness of the whole house, the IZ, and the remaining pressurization zone, the research team conducted multipoint tightness tests. The test data were used to construct a best-fit equation. This equation could be used to predict a pressure differential at different zone fan flow rates; however, it is more accurate predicting at pressures above $15 \mathrm{~Pa}$ because wind just under $10 \mathrm{mph}$ can cause variations of a few pascals, and pressure test data typically starts at $15 \mathrm{~Pa}$ or higher. The depressurization method of Standard ASTM E779 was used to determine 
Lab Home Testing of Residential Isolation Space Control to Minimize Infectious Disease Transmission in Existing Single-Family Homes

airtightness. The calibrated fans used were an Energy Conservatory Blower Door with a digital manometer and a DuctBlaster fan with a digital manometer. The blower door was used for the MZ tightness, and the DuctBlaster was used on the smaller IZ. The Blower Door can measure from 85 CFM to about 5,000 CFM at 50 Pa pressure with an accuracy of $\pm 3 \%$. The DuctBlaster can measure from 10 CFM to about 1,400 CFM at 50 Pa pressure with an accuracy of $\pm 3 \%$.

Both guarded and unguarded tests were conducted to determine leakage between zones and leakage to outdoors. Results from these tests were used to estimate net (mechanical air entering zone - air exhausted) fan flow required to maintain critical pressure differentials.

\subsection{Airflow Measurements}

Airflow rates of mechanically conveyed air into and out of the test house were measured.

Airflows of bathroom exhaust were measured using a passive flow capture hood method. The window fan, supply grille flows, and portable room air-conditioning exhaust flow were measured using a powered flow capture hood method. The Energy Conservatory Exhaust Fan Flow Meter is a passive flow hood design that consists of a plastic manufactured box with an adjustable flow orifice and a DG-700 digital manometer. After placing the flow box over the exhaust fan intake, the pressure in the box and the known orifice size are used with the manufacturer's calibration to calculate airflow. This method is suitable for bathroom exhaust flows under about 124 CFM.

The accuracy of this device is $\pm 10 \%$ of reading when the box pressure limit stays within $-8.0 \mathrm{~Pa}$ to $-1.0 \mathrm{~Pa}$.

The powered capture hood method uses a hood that will fit over an intake or discharge of the device being measured. Because a passive hood may restrict the airflow of units with higher airflows, a calibrated fan with adjustable speed is connected to the hood. The pressure is measured in the capture hood, a calibrated fan is adjusted until the hood pressure is neutral, and then the airflow is measured. The Energy Conservatory DuctBlaster, a digital manometer, and a box were used as the powered flow hood device. This device can measure airflows from $10 \mathrm{CFM}$ to $1,500 \mathrm{CFM}$ and has an accuracy of $\pm 3 \%$.

\subsection{Pressure Differential, Temperature, and Wind Monitoring}

A Campbell Scientific data logger and data collection system was used to monitor zone air pressure differences, indoor and outdoor temperatures, wind speed, and wind direction. Data were sampled at 10 -second intervals and averaged at 15 -minute intervals. A central data collection system downloaded and screened data for errors and then stored it on a secured database.

Pressure differentials were measured to determine the expected direction of airflow and were used as the key indicator for isolation containment. Air flows through pathways from a zone of higher pressure to one of lower pressure. The pressure differential of the IZ with reference to the house main body, and the main body with reference to outdoors was measured under several 
Lab Home Testing of Residential Isolation Space Control to Minimize Infectious Disease Transmission in Existing Single-Family Homes

different house operational scenarios. Pressure measurements indicated pressure impacts from events such as:

- IZ door closure

- IZ supplies open and closed

- IZ bathroom exhaust fan operation

- Central heat and air on and off

- Operation of kitchen, central zone bathroom, or other exhaust, such as clothes dryer

- Window fan operation

- Open windows.

Differential pressures were measured using Energy Conservatory digital manometers with an analog output that enabled data logging. The manometers had a range of $-200 \mathrm{~Pa}$ to $+200 \mathrm{~Pa}$ and accuracy of $\pm 1 \%$ or $\pm 0.2 \mathrm{~Pa}$, whichever is greater. The accuracy of $\pm 0.2 \mathrm{~Pa}$ applies to the range of pressure measurements reported herein. The outdoor pressure reference tubing was run to an open lawn area about 50 feet to the south of the house lab, with a static pressure probe installed at the end. Indoor pressure tubes were located away from direct velocity of fans or supply air discharge.

Temperatures were measured with Vaisala HMP 50 Temperature and Humidity sensors. Temperature accuracy was $\pm 0.5^{\circ} \mathrm{F}$. Wind speed and direction were measured on-site using Met One instruments. The wind speed had a starting threshold of $1 \mathrm{mph}$ and accuracy of $\pm 1.5 \%$, or $0.25 \mathrm{mph}$. Wind direction was measured as degrees from north $\left(0^{\circ}, 360^{\circ}\right)$ and had an accuracy of $\pm 5^{\circ}$.

\subsection{Isolation Zone Containment Testing Using $\mathrm{PM}_{2.5}$}

Although sizes of most respiratory viruses (e.g., rhinovirus, adenovirus, and SARS-CoV-2) are very small (i.e., 0.3-0.12 $\mu \mathrm{m}$ ) (Fehr and Perlman 2015), existing evidence suggests that airborne particles could play an important role in the transmission of respiratory viruses such as SARSCoV-2 (Qu et al. 2020; Riccò et al. 2020). This means that fine particulate matter could act as a carrier for SARS-CoV-2 (Tung et al. 2021). The virus-laden particles may remain suspended in the air for prolonged periods, especially particles having a smaller diameter (Tellier 2006) with a low removal rate from air to surface, while the larger particles are subject to fast settling on surfaces (Khan and Perlinger 2017). Several recent studies reported that indoor particulate matter generated from tobacco smoking, incense burning, laser printing, and similar actions could facilitate the transmission of SARS-CoV-2 in indoor environments (Amoatey et al. 2020; Mahabee-Gittens et al. 2020; He and Han 2020).

In this project, $\mathrm{PM}_{2.5}$ was used as a marker for virus transmission and for evaluating the effectiveness of containment strategies. $\mathrm{PM}_{2.5}$ was generated using essential oil with deionized (DI) water in a diffuser located within the IZ, and resulting concentrations were monitored in the IZ and MZ. No other activities such as cooking, smoking, vacuuming, or similar were performed 
Lab Home Testing of Residential Isolation Space Control to Minimize Infectious Disease Transmission in Existing Single-Family Homes

in the laboratory home during the experiments. As a result, the background $\mathrm{PM}_{2.5}$ concentrations in both $\mathrm{IZ}$ and $\mathrm{MZ}$ remained very low (mean $1-3 \mu \mathrm{g} \mathrm{m}^{-3}$ ). To enable meaningful evaluation of containment strategies before and after an intervention, the target quasi-steady-state $\mathrm{PM}_{2.5}$ concentrations in the IZ were set at least a factor of 50 higher than the mean background concentration. $\mathrm{PM}_{2.5}$ was also measured outdoors because unusually high ambient $\mathrm{PM}_{2.5}$ concentrations (such as those normally found during forest fires, prescribed biomass burning, etc.) could potentially impact background $\mathrm{PM}_{2.5}$ concentrations. Generally, the mean ambient $\mathrm{PM}_{2.5}$ concentration at the experimental site location was 5-7 $\mu \mathrm{g} \mathrm{m}^{-3}$, well below the U.S. Environmental Protection Agency's 24-hour standard of $35 \mu \mathrm{g} \mathrm{m}^{-3}$.

$\mathrm{PM}_{2.5}$ concentrations in multiple zones in the house were measured using co-located researchgrade (MetOne BT-645 Portable Dust Monitor) and commercially available low-cost (IQAir AirVisual Pro) instruments. These monitors record concentration data at a temporal resolution of 10 to 60 seconds. An airflow rate of $2 \mathrm{~L} \mathrm{~min}^{-1}$ was used in the MetOne indoor monitor.

Background $\mathrm{PM}_{2.5}$ measurements were conducted before generating aerosols in the IZ. The measured background concentrations were used as the baseline "zero" reading.

\subsection{Isolation Zone Containment Testing Using Tracer Gas}

In addition to $\mathrm{PM}_{2.5}$, a tracer gas (sulfur hexafluoride, $\mathrm{SF}_{6}$ ) was used to determine IZ containment potential effectiveness under different residential building operational scenarios. The tracer gas was applied within the IZ. After tracer gas was injected into the IZ and allowed time to diffuse, several measurements of concentration in parts per billion ( $\mathrm{ppb}$ ) were taken at 5to 10-minute intervals over continuous periods within the IZ and also in the main house zone using a ThermoFisher Scientific Miran Analyzer 205B-XLA4N. This unit measured $\mathrm{SF}_{6}$ to a resolution of $10 \mathrm{ppb}$ with accuracy of $\pm 10 \%$ from 0 to $1,000 \mathrm{ppb}$, and $\pm 20 \%$ from 1,000 to $4,000 \mathrm{ppb}$. Testing was conducted with gas concentrations typically in the range from $80 \mathrm{ppb}$ up to $8,000 \mathrm{ppb}$. Some tests with very high IZ ventilation rates started with higher concentrations that would drop in half within 20 minutes. The zero drift of the gas analyzer was checked with a zero gas filter and measured outdoors during testing. The concentration in the MZ was compared to the IZ during each test case scenario.

\subsection{Test Cases and Configurations}

A total of 17 test cases were conducted in the manufactured housing laboratory (Figure 1). Most test cases were repeated three times and some twice. This study focused on the investigation of effectiveness of controls for common configurations, not a systematic study of all variables. The cases were selected based on some likely combinations of HVAC settings in occupied homes, as well as potential control measures that could be implemented by most occupants.

Tests focused on evaluating various means of practical effort. This covered actions including no effort made by occupants (baseline), basic efforts using existing available means already in the home, and efforts likely requiring the purchase of other fans or personal comfort equipment that can be obtained within several days. The use of bath exhaust and window fans, open windows, 
Lab Home Testing of Residential Isolation Space Control to Minimize Infectious Disease Transmission in Existing Single-Family Homes

IZ door closure, and blocking central air from IZ are examples of types of measures tested. All test cases did not involve any other door closures in the home other than the IZ door. Only the IZ door was manipulated. The two other bedrooms and one hall bathroom door remained open and were considered part of the MZ. It is important to note, however, that closing bedroom doors are already known to result in MZ depressurization w.r.t. outdoors and other closed-door rooms. This can occur in homes with central ducted heat and air having only a single return from the MZ (Cummings et al. 1990; Swami et al. 2006). This impact would undermine IZ containment but is less likely if the rooms part of MZ have adequate return air.

All the cases with their test configuration details are listed in Table 1.

Table 1. Test Case Configurations

\begin{tabular}{|c|c|c|c|c|c|c|c|}
\hline $\begin{array}{c}\text { Case } \\
\#\end{array}$ & $\begin{array}{l}\text { IZ Door } \\
\text { State }\end{array}$ & $\begin{array}{c}\text { IZ Bath } \\
\text { Exhaust } \\
\text { Fan }\end{array}$ & $\begin{array}{c}\text { Window } \\
\text { Fan }\end{array}$ & $\begin{array}{l}\text { IZ Window(s) } \\
\text { State }\end{array}$ & $\begin{array}{c}\text { MZ } \\
\text { Window(s) } \\
\text { State }\end{array}$ & $\begin{array}{l}\text { Central } \\
\text { Heating/ } \\
\text { Coolings }\end{array}$ & $\begin{array}{l}\text { IZ Supply } \\
\text { Grilles }\end{array}$ \\
\hline 1 & Open & Off & No & Closed & Closed & On & Open \\
\hline 2 & Open & On & No & Closed & Closed & On & Open \\
\hline 3 & Closed & Off & No & Closed & Closed & On & Closed \\
\hline 4 & Closed & Off & $\begin{array}{l}\text { In IZ as } \\
\text { exhaust }\end{array}$ & Closed & Closed & On & Closed \\
\hline 5 & Closed & On & No & Closed & Closed & On & Closed \\
\hline 6 & Closed & On & $\begin{array}{c}\text { In MZ as } \\
\text { supply }\end{array}$ & Closed & Closed & On & Closed \\
\hline 7 & Closed & Off & $\begin{array}{c}\text { In MZ as } \\
\text { supply }\end{array}$ & Closed & Closed & On & Closed \\
\hline 8 & Closed & On & No & Open (1) & Closed & Off & Closed \\
\hline 9 & Closed & On (low) & No & Closed & Closed & On & Closed \\
\hline 10 & \multicolumn{7}{|c|}{$\begin{array}{c}\text { Monitoring IZ containment during IZ to MZ door opening/closing } \\
\text { under conditions for Case } 5\end{array}$} \\
\hline 11 & Closed & On & No & Closed & Closed & On & Open \\
\hline 12 & Closed & Off & $\begin{array}{l}\text { In IZ as } \\
\text { exhaust }\end{array}$ & Closed & Closed & On & Open \\
\hline 13 & Closed & Off & No & Closed & Open (2) & Off & Closed \\
\hline 14 & Closed & On & No & Closed & Closed & On & $\begin{array}{c}\text { Open } \\
\text { (partial) }\end{array}$ \\
\hline 15 & Closed & Off & No & Open (2) & Closed & Off & Closed \\
\hline $16^{*}$ & Closed & Off & Off & Closed & Closed & Off & Closed \\
\hline $17^{* *}$ & Closed & Off & Off & Closed & Closed & On & Closed \\
\hline
\end{tabular}

Note: All tests including IZ bath exhaust fan "On" were conducted at a high fan speed setting unless otherwise specified. The number in parentheses for window state denotes the number of windows open during the test in the IZ and/or MZ.

sHVAC fan ON Continuous

*Use of kitchen range hood in the MZ simulated using a duct blaster (flow: 100 CFM, duration: 30 minutes).

**A portable room air conditioner with exhaust to outside installed in one of the IZ windows. 
Lab Home Testing of Residential Isolation Space Control to Minimize Infectious Disease Transmission in Existing Single-Family Homes

Following are general explanations for some of the types of test cases:

- Case 1 demonstrates a baseline case where no effort is made.

- Case 2 is a baseline with the simple effort of using an existing fan, but not closing the IZ door.

- Cases 3-17 address closing the IZ door with other variations.

- Cases 1, 2, 11, and 14 involve IZ central air on and IZ supply grilles not sealed off.

- Cases 8, 13, and 15 involve open window configurations with other variations.

- The impact from different IZ bath exhaust cases is covered in Cases 2, 5, 6, 8, 9, 11, and 14.

- The impact of a low-cost window fan installed in an IZ or MZ is covered in Cases 4, 6, 7, and 12 .

- The impact of MZ exhaust such as a range hood or other exhaust fan is covered by Case 16. This is similar to Case 3, except the exhaust event and central air is turned off.

- Because an effective case requiring the IZ door kept closed would occasionally require door opening for practical purposes such as tending the isolated person, Case 10 is an evaluation of a reasonably effective case (Case 5) that had variations in door opening events (i.e., the door was open and closed for various durations during the test). 
Lab Home Testing of Residential Isolation Space Control to Minimize Infectious Disease Transmission in Existing Single-Family Homes

\section{Results}

This section is divided into subsections summarizing the following results: airflow characteristics and building airtightness (Section 4.1), environmental data/test parameters (Section 4.2), best and worst containment test cases (Section 4.3), and special test cases (Section 4.4).

\subsection{Airflow Characteristics and Building Airtightness}

To create depressurization in the IZ, we used a bathroom exhaust fan (within the IZ) and a portable low-cost window fan. The bathroom exhaust fan was capable of operating at three different speeds. This fan was only tested at the high and low setting, because high speed could produce reasonable pressure control, and low speed was more similar to existing bath fans in most homes. The window fan had two settings, but there was only a 25-CFM difference between them, so the fan was operated at high speed when used. The portable room air conditioner, with an air exhaust duct kit, had a rated cooling output of 6,700 Btu/h (DOE test method) and 11,500 $\mathrm{Btu} / \mathrm{h}$ (ASHRAE test method). Table 2 summarizes the airflow measurements of different equipment.

Table 2. Airflow Characteristics

\begin{tabular}{|l|c|c|c|}
\hline \multicolumn{1}{|c|}{ Instrument } & Specification & Operating Modes & Measured Flow (CFM) \\
\hline \multirow{3}{*}{ Bath Exhaust Fan } & $\begin{array}{c}\text { Panasonic } \\
\text { FV-0511VK2 } \\
\text { WhisperGreen Select }\end{array}$ & High & 110 \\
\cline { 2 - 4 } Window Fan & $\begin{array}{c}\text { CCC Comfort Zone 9" } \\
\text { window twin fan }\end{array}$ & Low & 48 \\
\cline { 3 - 4 } & IZ Door Closed & Low & 328 \\
\cline { 2 - 4 } Supply Grilles & IZ Door Open & Open (full) & 303 \\
\cline { 2 - 4 } & Open (partial) & 172 \\
\hline \multirow{2}{*}{ Portable AC Unit } & $\begin{array}{c}\text { DeLonghi 6700 Btu/h } \\
\text { output }\end{array}$ & Open (full) & 192 \\
\hline
\end{tabular}

Building airtightness and zone airtightness was measured to document the tested leakage and verify that there were no unplanned air pathways between the IZ and MZ. The guarded tests measure the leakage of each zone to outdoors and do not include leakage between these two zones. The whole house tightness test represents the entire home as one zone. The test leakage is reported as the airflow rate in CFM that occurs when the tested zone with reference to outdoors is at $50 \mathrm{~Pa}$ pressure difference (CFM50). The CFM50 result was normalized for zone volume and converted to air changes per hour at 50 (ACH50). ACH50 allows a better comparison of airtightness between different houses or zones. The air leakage results are shown in Table 3 . 
Lab Home Testing of Residential Isolation Space Control to Minimize Infectious Disease Transmission in Existing Single-Family Homes

CFM50 is directly proportional to the cumulative air leak size, so larger floor areas generally have more leakage area and therefore higher CFM50 values. This can be observed comparing the whole house test to the IZ leakage and the outdoors test. When the normalized air leakage $\mathrm{ACH} 50$ is compared, however, the IZ appears to be relatively leakier than the whole house, and the MZ has a similar ACH50 to the whole house. Overall, the relative tightness of the house and each zone can be considered representative of many existing single-family homes in the United States.

The leakage of the partition wall between the IZ and MZ was determined using the difference between the total IZ tightness (leakage from outdoors and adjacent indoor zones) and guarded IZ test tightness (leakage only directly from outdoors). The partition wall, including the IZ door undercut pathway, represented about $45 \%$ of the total tightness. The door undercut represented $22 \%$ of the total IZ tightness.

Table 3. Summary of Airtightness Test Results

\begin{tabular}{|l|c|c|c|c|c|}
\hline \multicolumn{1}{|c|}{ Test Description } & CFM50 & ACH50 & $\begin{array}{c}\text { Floor Area } \\
\left(\mathbf{f t}^{2}\right)\end{array}$ & $\begin{array}{c}\text { Flow Leak } \\
\text { C }\end{array}$ & $\begin{array}{c}\text { Flow Leak } \\
\mathbf{n}\end{array}$ \\
\hline Whole house & 1,316 & 5.2 & 1,620 & 100.8 & 0.657 \\
\hline IZ leakage to out (guarded test) & 317 & 6.0 & 384 & 23.2 & 0.669 \\
\hline MZ leakage to out (guarded test) & 956 & 4.8 & 1,236 & 82.2 & 0.627 \\
\hline
\end{tabular}

\subsection{Environmental Data}

Our team performed simultaneous measurements of several key environmental parameters, including pressure differential (dP) in the isolation zone (IZ w.r.t. MZ) and in the main zone (MZ w.r.t. outside), central air supply pressure, indoor and outdoor temperature and relative humidity, and wind speed. Table 4 shows the statistical summary of three select parameters. For each experimental case, the statistical parameter values (mean, minimum, and maximum) were calculated using the ensemble data obtained from two or three repeat tests. Data QA/QC was performed before calculating the statistical metrics.

The primary metric used in this project to evaluate potential containment effectiveness is the IZ w.r.t. MZ pressure difference. ASHRAE Standard 170 was used as guidance on a suitable IZ w.r.t. $M Z$ pressure limit. ASHRAE 170 requires a hospital isolation room pressure differential of at least -2.5 Pa w.r.t. adjacent zones as well as several other matters not part of this research. Higher IZ pressure (toward zero or positive values) indicates inadequate pressure gradient and more potential for diminished containment control. 
Lab Home Testing of Residential Isolation Space Control to Minimize Infectious Disease Transmission in Existing Single-Family Homes

Table 4. Statistical Summary of Select Environmental Data

\begin{tabular}{|c|c|c|c|c|c|c|c|c|c|}
\hline & \multicolumn{3}{|c|}{ IZ dP w.r.t. MZ (Pa) } & \multicolumn{2}{c|}{ MZ dP w.r.t. Outside (Pa) } & \multicolumn{3}{c|}{ Mean Temp. $\left({ }^{\circ} \mathrm{F}\right)$} \\
\hline Case \# & Mean & Min. & Max. & Mean & Min. & Max. & I & MZ & Out \\
\hline 1 & 0.0 & 0.0 & 0.0 & -1.1 & -2.6 & 0.4 & 68.0 & 71.2 & 61.5 \\
\hline 2 & -0.3 & -2.0 & 0.0 & -2.2 & -3.3 & -0.8 & 70.5 & 72.7 & 63.8 \\
\hline 3 & -0.2 & -0.3 & 0.0 & -0.7 & -2.2 & 0.5 & 68.1 & 72.8 & 65.0 \\
\hline 4 & -7.0 & -7.8 & -6.6 & -2.0 & -2.6 & -0.5 & 75.3 & 71.8 & 77.9 \\
\hline 5 & -2.7 & -2.9 & -2.5 & -0.7 & -0.9 & -0.5 & 85.9 & 77.0 & 82.2 \\
\hline 6 & -5.6 & -7.0 & -3.9 & 3.2 & 2.2 & 3.9 & 74.3 & 69.4 & 75.2 \\
\hline 7 & -1.6 & -2.6 & -1.0 & 3.9 & 3.1 & 4.7 & 75.0 & 69.9 & 76.2 \\
\hline 8 & -0.8 & -2.4 & 0.5 & -0.3 & -1.3 & 1.3 & 80.0 & 79.7 & 81.0 \\
\hline 9 & -0.9 & -1.2 & -0.7 & -0.8 & -1.4 & 0.0 & 82.0 & 76.9 & 78.6 \\
\hline 10 & & Monitoring IZ door opening/closing under conditions for Case 5 & \\
\hline 11 & 2.0 & 1.3 & 2.9 & -2.0 & -2.7 & -1.0 & 70.4 & 70.9 & 78.6 \\
\hline 12 & -1.2 & -2.9 & -0.2 & -3.6 & -4.4 & -2.4 & 76.4 & 76.3 & 78.1 \\
\hline 13 & -0.1 & -0.4 & 0.0 & -0.2 & -0.8 & 0.5 & 74.6 & 75.7 & 72.5 \\
\hline 14 & -0.7 & -1.0 & -0.4 & -1.7 & -2.5 & -0.9 & 67.3 & 71.5 & 65.7 \\
\hline 15 & 0.3 & -0.2 & 0.7 & -0.9 & -1.8 & -0.3 & 65.6 & 73.0 & 58.4 \\
\hline 16 & -0.2 & -0.4 & 0.2 & -0.9 & -2.7 & 0.4 & 70.4 & 73.2 & 66.8 \\
\hline 17 & -5.4 & -6.2 & -2.3 & -2.5 & -3.7 & -0.7 & 73.4 & 75.0 & 77.8 \\
\hline
\end{tabular}

When IZ w.r.t. MZ dP was compared to the benchmark value of $-2.5 \mathrm{~Pa}$, four cases $(4,5,6$, and 17) met and/or exceeded (more negative) this threshold. The resulting IZ differential pressure (IZ $\mathrm{dP}$ ) data for 13 cases exhibited inadequate depressurization of the IZ (Table 4). The test conditions for two cases (11 and 15) were unable to create any depressurization in the IZ. Cases such as 7 and 12 could be considered moderate containment strategies because the $\mathrm{dP}$ values were slightly less negative than $-2.5 \mathrm{~Pa}$.

A few general comments and test conclusions can be drawn from Table 4 and are offered here:

- Methods involving the IZ door and supplies being closed and IZ air exhausted to outdoors using at least 110 CFM offered effective containment (Cases 4, 5, 6, and 17).

- An open door between the IZ and MZ with open supply grilles during heating or cooling offered no containment (Case 1), and operation of an IZ exhaust at 110 CFM was still not adequate with the IZ open door (Case 2).

- Closing the IZ door and sealing IZ supply grilles with no mechanically moving air across the IZ zone is not adequate (Case 3).

- Opening windows (Cases 8, 13, 15) helps ventilate and dilute pollutants; however, the effectiveness depends on wind speed and direction. When the wind blew into IZ windows, 
Lab Home Testing of Residential Isolation Space Control to Minimize Infectious Disease Transmission in Existing Single-Family Homes

it tended to produce positive pressure in IZ w.r.t. MZ (Case 15). However, when the wind was not blowing into open IZ windows, there was slight negative pressure (Case 8).

- Although closing doors, blocking IZ supply air, and using IZ exhaust of at least $110 \mathrm{CFM}$ outdoors was reasonably effective in these tests, a serious drawback was that during very warm or cold weather, the ill person in the IZ is likely to experience uncomfortable room thermal conditions (as can be observed in comparing IZ and $\mathrm{MZ}$ mean room temperatures shown in Table 4). For example, Case $5 \mathrm{IZ}$ temperature was $8.9^{\circ} \mathrm{F}$ warmer than the $\mathrm{MZ}$ and $3.7^{\circ} \mathrm{F}$ warmer that outdoors. And, opening the supply grilles to a central air system may totally negate the IZ depressurization (Case 11).

- Case 17, which used a portable room air conditioner, was effective at maintaining adequate negative pressure in the IZ and comfortable conditions during warm weather. Cost is a drawback, with typical retail for a unit that can handle a master bedroom between $\$ 300$ and $\$ 600$.

- It is expected that IZ containment in a residence would only need to be instituted for a short-term period of less than a month. However, in the event a longer-term depressurization of an IZ w.r.t. outdoors is anticipated, homes in humid climates should be aware of the potential for moisture-related durability issues during humid outdoor weather. Such concerns arise when outdoor dew points are high (exceeding $72^{\circ} \mathrm{F}$ ), and due to the long-term infiltration of the humid air that results from space depressurization. While most modern homes are unlikely to have any problems, moisture-related durability issues may occur if the IZ has vapor-impermeable floor or wall coverings, such as vinyl wallpaper, and/or if the IZ is cooled to temperatures below outdoor dew point temperatures (Moyer et al. 2001).

\subsection{Best and Worst Containment Test Cases}

Collectively, the pressure differential data (Table 5) and the indoor air quality measurement data obtained from the diffuser and tracer gas tests enabled us to determine the most effective means to maintaining pressure differentials and creating containment in an isolation space.

Simultaneous measurements of $\mathrm{PM}_{2.5}$ and tracer gas in both the IZ and $\mathrm{MZ}$ during the period of an intervention (e.g., bathroom exhaust fan or IZ window fan operation) were used to estimate concentration ratios $(\mathrm{MZ} / \mathrm{IZ})$ for both species. Together, these ratios and pressure differential values (IZ dP) were further examined to determine the best and worst containment strategies. In Table 5, the four best and four worst cases are listed. 
Lab Home Testing of Residential Isolation Space Control to Minimize Infectious Disease Transmission in Existing Single-Family Homes

Table 5. Differential Pressure and Concentration Ratios for PM 2.5 and Tracer Gas

\begin{tabular}{|c|c|c|c|c|c|c|c|c|c|}
\hline \multirow[b]{2}{*}{ Type } & \multirow[b]{2}{*}{$\begin{array}{c}\text { Case } \\
\#\end{array}$} & \multicolumn{3}{|c|}{ IZ dP w.r.t. MZ (Pa) } & \multirow{2}{*}{$\begin{array}{c}\text { MZ dP } \\
\text { w.r.t. } \\
\text { Out (Pa) } \\
\text { Mean }\end{array}$} & \multirow{2}{*}{$\begin{array}{c}\mathrm{PM}_{2.5} \\
(\mathrm{MZ} / \mathrm{Z}) \\
\text { Mean }\end{array}$} & \multirow{2}{*}{$\begin{array}{c}\text { Tracer } \\
\text { Gas } \\
(\mathrm{MZ} / \mathrm{ZZ})\end{array}$} & \multirow{2}{*}{$\begin{array}{l}\text { Wind } \\
\text { Speed } \\
\text { (mph) }\end{array}$} & \multirow{2}{*}{$\begin{array}{c}\begin{array}{c}\text { Wind } \\
\text { Direction } \\
\text { (Degrees } \\
\text { From North) }\end{array} \\
\text { Mean }\end{array}$} \\
\hline & & Mean & Min. & Max. & & & & & \\
\hline \multirow{4}{*}{ Best } & 4 & -7.0 & -7.8 & -6.6 & -2.0 & 0.068 & 0.080 & 6.2 & $88 \mathrm{~S}$ \\
\hline & 5 & -2.7 & -2.9 & -2.5 & -0.7 & 0.054 & 0.085 & 5.5 & $93 \mathrm{~S}$ \\
\hline & 6 & -5.6 & -7.0 & -3.9 & 3.2 & 0.033 & 0.067 & 7.2 & $164 \mathrm{~S}$ \\
\hline & 17 & -5.4 & -6.2 & -2.3 & -2.5 & 0.284 & 0.099 & 7.4 & $181 \mathrm{~S}$ \\
\hline \multirow{4}{*}{ Worst } & 1 & 0.0 & 0.0 & 0.0 & -1.1 & 0.572 & 0.779 & 5.1 & $194 \mathrm{~S}$ \\
\hline & 2 & -0.3 & -2.0 & 0.0 & -2.2 & $N / A$ & 0.683 & 5.5 & $230 \mathrm{SW}$ \\
\hline & 8 & -0.8 & -2.4 & 0.5 & -0.3 & 0.374 & 0.411 & 6.8 & 224 SW \\
\hline & 11 & 2.0 & 1.3 & 2.9 & -2.0 & 0.292 & 0.640 & 6.5 & $78 \mathrm{E}$ \\
\hline
\end{tabular}

Generally, a lower MZ/IZ value (close to 0) for both $\mathrm{PM}_{2.5}$ and tracer gas denotes a strong IZ containment. However, operating conditions of the IZ during an experiment affect the decay rate of injected aerosols and/or tracer gas, which could result in a fast decrease in concentrations in the IZ. In such cases, even a small increase in concentrations in MZ could result in large MZ/IZ ratios, which could infer containment that is worse than actual. Considering this caveat, we examined the $\mathrm{MZ} / \mathrm{IZ}$ values in the context of pressure differentials (e.g., IZ dP) while determining the best and worst case containment scenarios listed in Table 5.

We can see in Table 5 that Case $4(\mathrm{MZ} / \mathrm{IZ}=0.068$ to 0.080$)$ provided the strongest containment, as the resulting $\mathrm{dP}$ in the IZ exceeded the minimum IZ pressure requirement by a factor of $\sim 3$. Case 4 ran a portable window fan as an exhaust fan to create IZ depressurization while keeping the IZ door closed at all times. In Case 6, this window fan was relocated in the MZ and operated as a supply fan installed in one of the $\mathrm{MZ}$ windows while the bathroom exhaust fan in the IZ was $\mathrm{ON}$. The resulting pressure differential (IZ dP) ranged from -7.0 to $-3.9 \mathrm{~Pa}$, providing more than enough depressurization for the minimum threshold requirement of $-2.5 \mathrm{~Pa}$. Consequently, the $\mathrm{MZ} / \mathrm{IZ}$ values ranged from 0.033 to 0.067 .

The data from Case 5 reveal that a bathroom exhaust fan with a flow of $\sim 100$ CFM is capable of creating adequate depressurization $(\mathrm{dP}=-2.7 \mathrm{~Pa})$ in the IZ. However, in practice, it is common to find a bathroom exhaust fan delivering an exhaust flow much less than 100 CFM. In such cases, this strategy might not be able to create a strong containment in the IZ unless the IZ is very airtight or a small room. In Case 17, a portable room air conditioner was used, exhausting indoor air to outdoors at 227 CFM. Table 5 shows that Case 17 achieved strong IZ depressurization $(-5.4 \mathrm{~Pa})$. The use of a portable air conditioner could help maintain comfort and also be used to maintain depressurization as long as it is cooling. In contrast, the worst cases $(1,8$, and 11$)$ had 
Lab Home Testing of Residential Isolation Space Control to Minimize Infectious Disease Transmission in Existing Single-Family Homes

$\mathrm{dP}$ (IZ) values ranging from -0.8 to $+2.0 \mathrm{~Pa}$, indicating very weak IZ containment. The values of $\mathrm{MZ} / \mathrm{IZ}$ for these cases are also very large. They ranged from 0.411 to 0.779 , suggesting a strong transfer of $\mathrm{PM}_{2.5}$ and/or tracer gas from the IZ to $\mathrm{MZ}$.

Figure 2 compares these seven cases (grouped into two categories, best and worst) using the concentration ratios (MZ/IZ for $\mathrm{PM}_{2.5}$ and tracer gas) and mean pressure differential (IZ $\mathrm{dP}$ ) values.

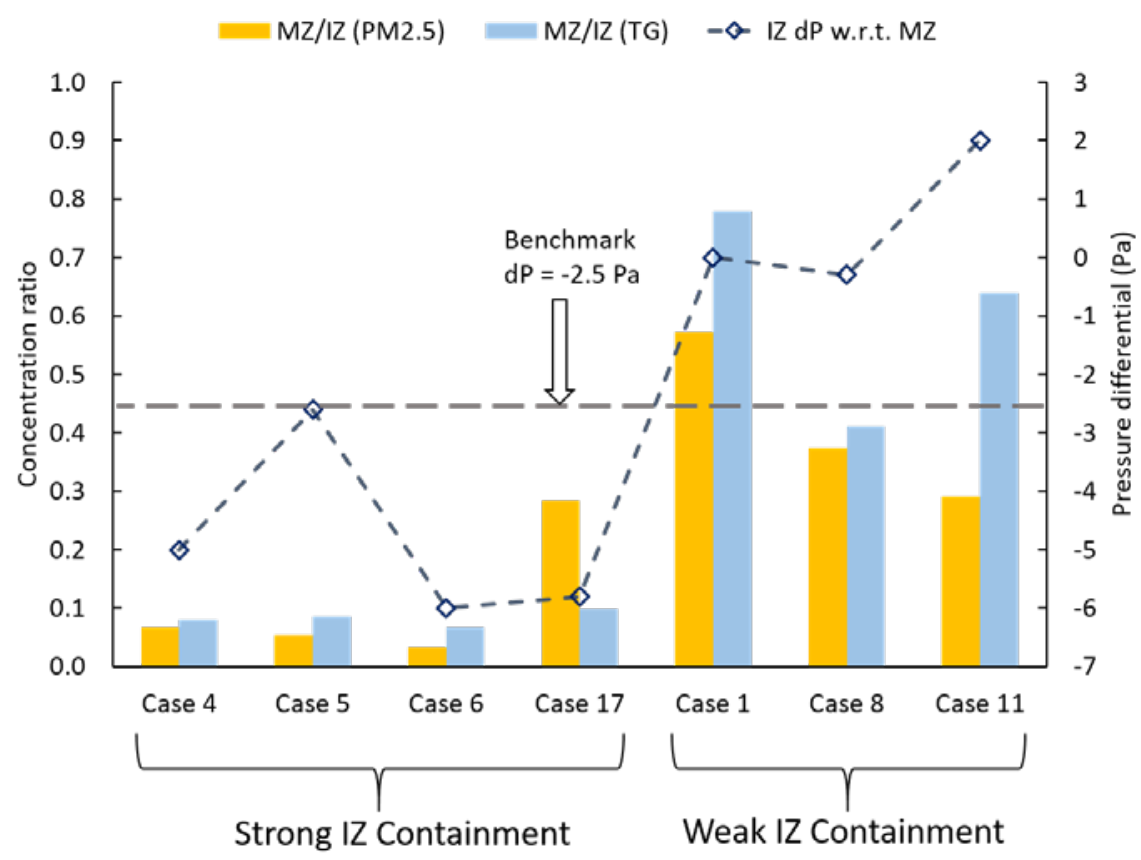

Figure 2. Comparison between strong and weak containment strategies

\subsubsection{Examples of Four Best Containment Strategies}

In this section, illustrative examples for Cases 4, 5, 6, and 17 are presented for $\mathrm{PM}_{2.5}$. For each case, the measurement duration is divided into four subcategories: background, $\mathrm{PM}_{2.5}$ build-up, intervention, and post-intervention. Background refers to the period before aerosol generation and any intervention applied; $P M_{2.5}$ build-up refers to the period when the diffuser was turned on, generating aerosols in the IZ without an intervention; intervention refers to the experimental period when an isolation intervention was applied while the diffuser was still continuously emitting aerosols; and post-intervention refers to the period when aerosol generation and containment control was discontinued.

\subsubsection{Case 4}

In this test example, depressurization in the IZ was created by running the portable window fan (as exhaust) at high-speed setting (delivering 328 CFM). In this particular test, we experienced difficulties generating strong $\mathrm{PM}_{2.5}$ signal from the diffuser $(11: 30$ to $\sim 13: 15)$ in the IZ. The issue was fixed at around 13:15. For calculation purpose (i.e., MZ/IZ), we considered the intervention period from 13:15-14:15. As can be seen from Figure 3, during this period (13:15-14:15), $\mathrm{PM}_{2.5}$ concentrations in the IZ were a factor of $\sim 20$ higher than $\mathrm{MZ}$ concentrations. Throughout the 
intervention period (14:15-15:15), a rapid decline in IZ concentration was observed, primarily due to operating the window exhaust fan, which expelled a majority of the particles outside the building. The observed negative pressure in the IZ also supports this notion. No noticeable increase in the $\mathrm{MZ}$ concentration (as compared to the background and pre-intervention concentrations in the $\mathrm{MZ}$ ) was observed during the window exhaust fan operation, suggesting very little to no transfer of air from IZ to MZ.

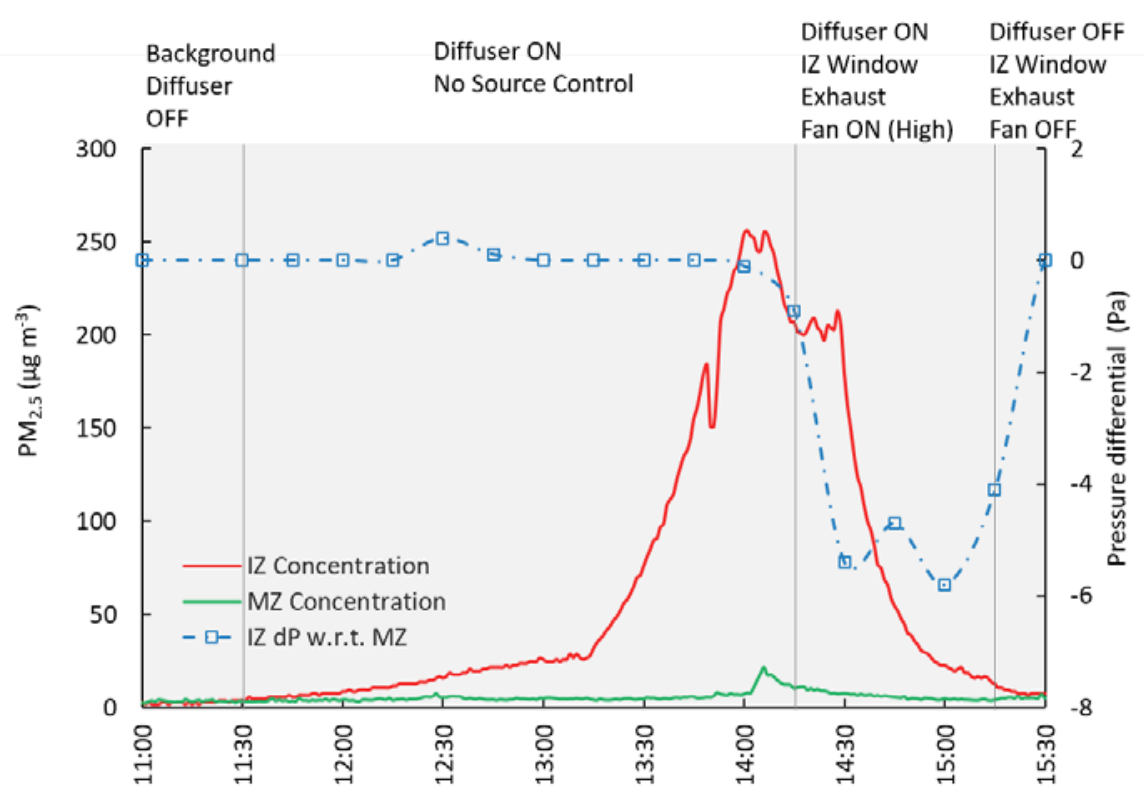

Figure 3. Time-series of $\mathrm{PM}_{2.5}$ for Case 4

\subsubsection{Case 5}

In this test example, depressurization in the IZ was created by running a bathroom exhaust fan at a high-speed setting (delivering 110 CFM). As can be seen in Figure 4, during the start of this period (16:15-17:36), $\mathrm{PM}_{2.5}$ concentrations in the IZ and $\mathrm{MZ}$ were 174 and $1 \mu \mathrm{g} \mathrm{m}^{-3}$, respectively. Throughout the intervention period, we observed a rapid decline in IZ concentration, primarily due to operating the bathroom exhaust fan that transferred a majority of the particles outside the building and resulted in dilution as air from around the IZ infiltrated. The observed negative pressure in the IZ also supports this notion. No noticeable increase in the $\mathrm{MZ}$ concentration during the exhaust fan operation was observed, suggesting very little to no transfer of air from the IZ to the MZ. It can be seen in Figure 4 that during the $\mathrm{PM}_{2.5}$ build-up period (14:40-16:14), $\mathrm{PM}_{2.5}$ concentrations in the $\mathrm{MZ}$ increased slightly from background concentration. During the pre-intervention period, Figure 4 shows the pressure was neutral at the time when the $\mathrm{PM}_{2.5}$ concentration increased. Because the door from IZ to $\mathrm{MZ}$ was closed and supply and return grilles in the IZ were completely sealed throughout the entire duration of this test, the increase in the $M Z$ was primarily attributed to air transfer from the $M Z$ to the IZ through the door undercut. This pattern was common in other test cases during the pre-intervention test period. 
Lab Home Testing of Residential Isolation Space Control to Minimize Infectious Disease Transmission in Existing Single-Family Homes

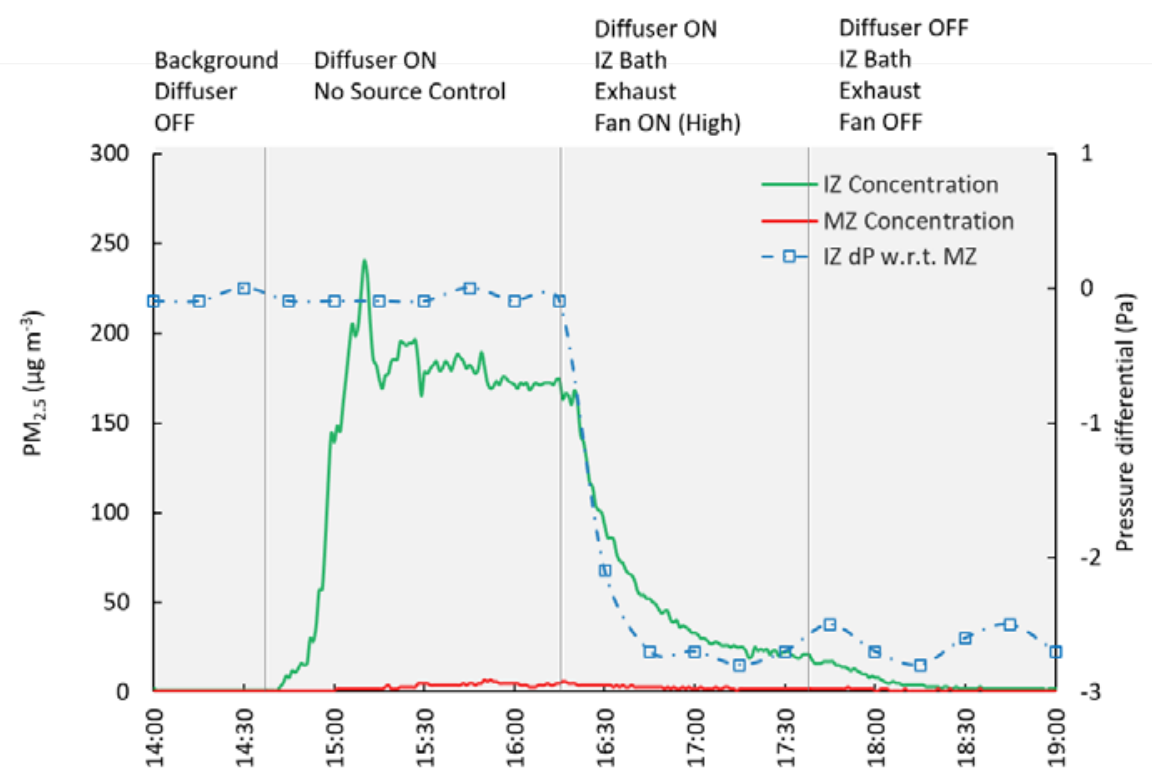

Figure 4. Time-series of $\mathrm{PM}_{2.5}$ for Case 5

\subsubsection{Case 6}

In this test example, depressurization in the IZ was created by running the window fan as supply (high-speed setting), delivering 328 CFM of supply air in the MZ. The IZ door and windows remained closed and no other intervention measures were imposed in the IZ. As can be seen in Figure 5, during the start of the intervention period (12:00-14:30), $\mathrm{PM}_{2.5}$ concentrations in the IZ and $\mathrm{MZ}$ were 185 and $2.5 \mu \mathrm{g} \mathrm{m}^{-3}$, respectively. Throughout the intervention period, a rapid decline in IZ concentration was observed, which is consistent with the prior two discussed cases. No noticeable increase in the MZ concentration during the exhaust fan operation was observed, suggesting very little to no transfer for air from IZ to MZ.

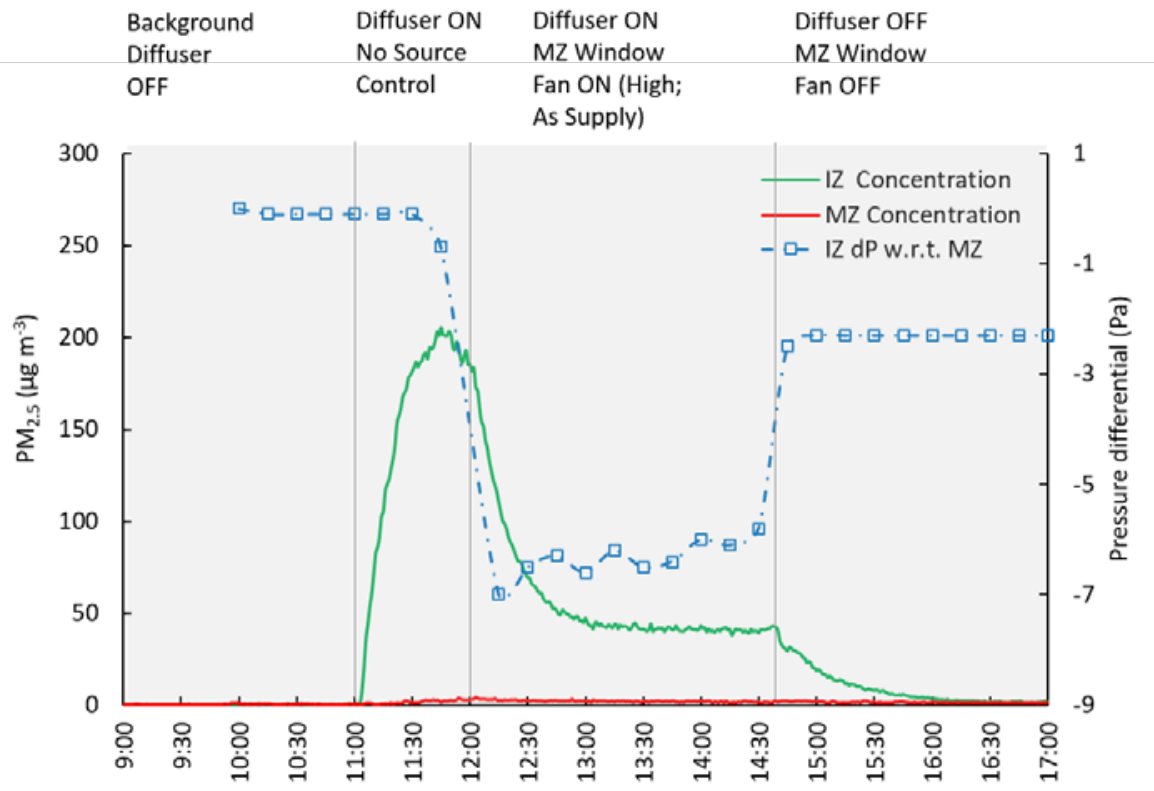

Figure 5. Time-series of $\mathrm{PM}_{2.5}$ for Case 6 
Lab Home Testing of Residential Isolation Space Control to Minimize Infectious Disease Transmission in Existing Single-Family Homes

\subsubsection{Case 17}

In this test example, depressurization in the IZ was created by a portable AC that exhausted 227 CFM of IZ air to the outside. Figure 6 shows $\mathrm{PM}_{2.5}$ and IZ pressure for Case 17. Prior to the containment test, the pre-test period allowed a build-up of concentration from about 12:0512:50. During this period, the MZ concentration can be observed increasing slightly with no measurable IZ w.r.t. $\mathrm{MZ}$ pressure difference $(0.0 \mathrm{~Pa})$. This is another demonstration that aerosols can move through leaks in closed doors from the IZ into the $\mathrm{MZ}$ at neutral pressure (particularly through the bottom of the door undercut). During the start of the intervention period (13:0215:00), $\mathrm{PM}_{2.5}$ concentrations in the $\mathrm{IZ}$ were a factor of $\sim 12$ higher than $\mathrm{MZ}$ concentrations. Throughout the intervention period, we observed a rapid decline in IZ concentration due to the increased infiltration of $\mathrm{MZ}$ and outdoor air from depressurization. This demonstrates the benefit of reducing elevated pollutant or viral load within the IZ. At the end of this period, the concentration in the $\mathrm{MZ}$ decreased by $\sim 2 \mu \mathrm{g} \mathrm{m}^{-3}$ from $5.33 \mu \mathrm{g} \mathrm{m}^{-3}$ (measured at 13:02), suggesting no air transfer from IZ to MZ. However, during the build-up period (12:00-13:01), air transfer from IZ to $\mathrm{MZ}$ through the door undercut occurred, increasing the mean $\mathrm{PM}_{2.5}$ concentrations by $\sim 2 \mu \mathrm{g} \mathrm{m}^{-3}$ from the mean background concentration of $1.3 \mu \mathrm{g} \mathrm{m}^{-3}$.

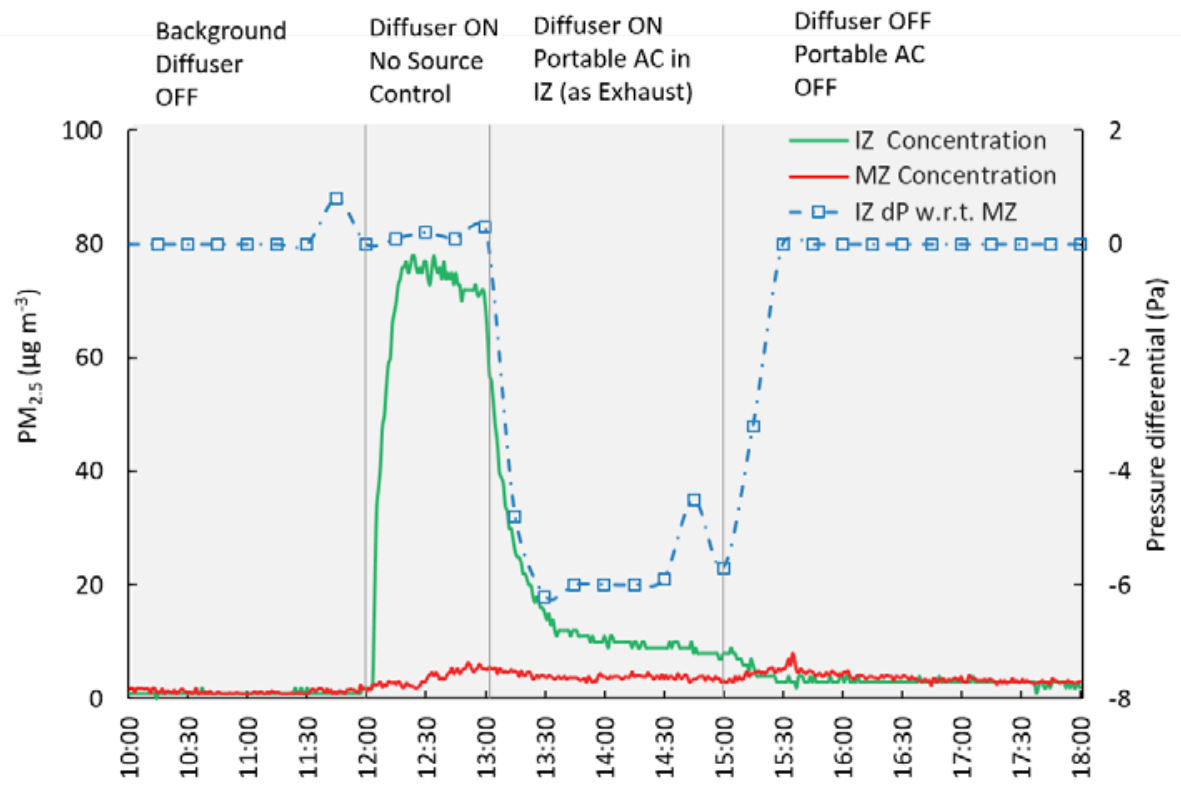

Figure 6. Time-series of $\mathrm{PM}_{2.5}$ for Case 17

\subsubsection{Examples of Three Weak Containment Strategies}

\subsubsection{Case 1}

In the example shown in Figure 7 for Case 1, the experimental data for the period 11:30-14:30 refer to the IZ door open scenario, while no intervention was applied. This test configuration resulted in neutral pressure $(0 \mathrm{~Pa}$ ) condition in the IZ (Figure 7). After the build-up period (10:30-11:30), opening the IZ door resulted in a rapid decline in $\mathrm{PM}_{2.5}$ concentrations in the IZ. At the same time, there has been a strong increase in concentration in the MZ. From 11:30 to 14:30, the mean $\mathrm{PM}_{2.5}$ concentrations in the $\mathrm{IZ}$ and $\mathrm{MZ}$ were within a factor of 2, while during 
the build-up period (with closed door), the mean concentration in the IZ was higher by a factor of $\sim 50$ from the mean $\mathrm{MZ}$ concentration. Collectively, these findings suggest this test configuration (i.e., open IZ door, open supply grilles in IZ, with central forced air on) has the least potential for IZ containment.

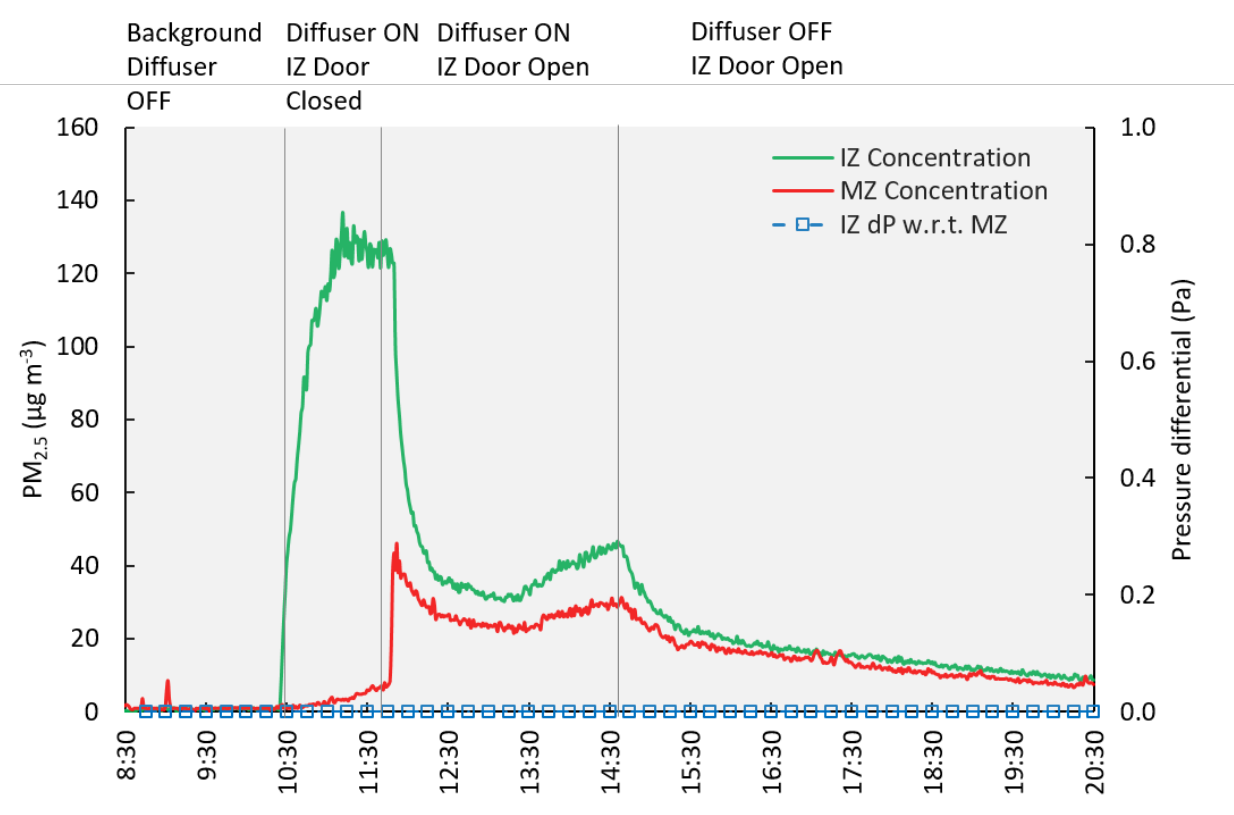

Figure 7. Time-series of $\mathrm{PM}_{2.5}$ for Case 1

\subsubsection{Case 8}

The large range $(-2.5$ to $+0.5 \mathrm{~Pa})$ in the measured IZ differential pressure data (Table 5) for this case suggests that the containment potential is highly dependent on outdoor conditions such as wind speed and direction, both of which could influence the pressure dynamics in the IZ room. Because of this uncontrollable external factor, the test results are challenging to generalize for a given indoor condition and IZ intervention approach (e.g., use of bathroom exhaust fan).

Figure 8 illustrates an example of this case, and shows a large fluctuation in the $\mathrm{dP}$ values during the intervention period (11:35-13:20). At the same time, $\mathrm{PM}_{2.5}$ concentrations also increased in the MZ. Given the strong dependency on wind conditions, the outcome of this test could be varied (from weak containment to strong containment). However, based on our differential pressure data (a mean of IZ dP of -0.8), this case is deemed a weak containment strategy. 
Lab Home Testing of Residential Isolation Space Control to Minimize Infectious Disease Transmission in Existing Single-Family Homes

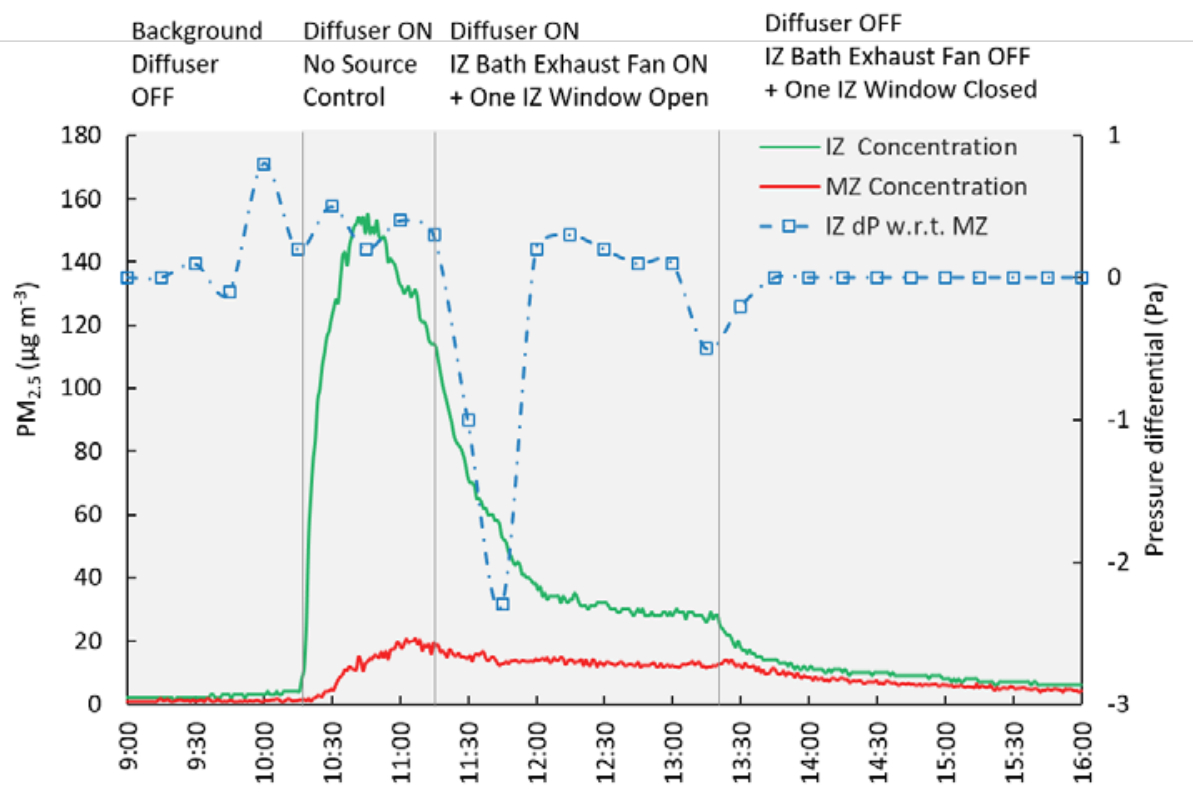

Figure 8. Time-series of $\mathrm{PM}_{2.5}$ for Case 8

\subsubsection{Case 11}

The test configuration for Case 11 attempts to address the comfort of the person in the IZ by allowing the HVAC system to deliver hot or cool air through supply grilles in the IZ while running the bathroom exhaust fan. Because of the opposing directions of airflow resulting from this configuration, it was critical to determine the net pressure differential resulting from the unbalanced (i.e., the difference between supply and exhaust) airflow in the IZ. As can be seen in Table 5, IZ remained positively pressured (mean $\mathrm{dP}=2.0 \mathrm{~Pa}$ ) throughout the intervention period. Figure 9 shows that during this period, although concentrations in the IZ decreased rapidly, there was a modest increase in $\mathrm{PM}_{2.5}$ levels in the MZ. Combining the data from pressure differential measurements and the observed high concentration ratios of MZ/IZ ( $\mathrm{PM}_{2.5}$ and tracer gas), this case can is considered to be one of the worst IZ containment strategies. 
Lab Home Testing of Residential Isolation Space Control to Minimize Infectious Disease Transmission in Existing Single-Family Homes

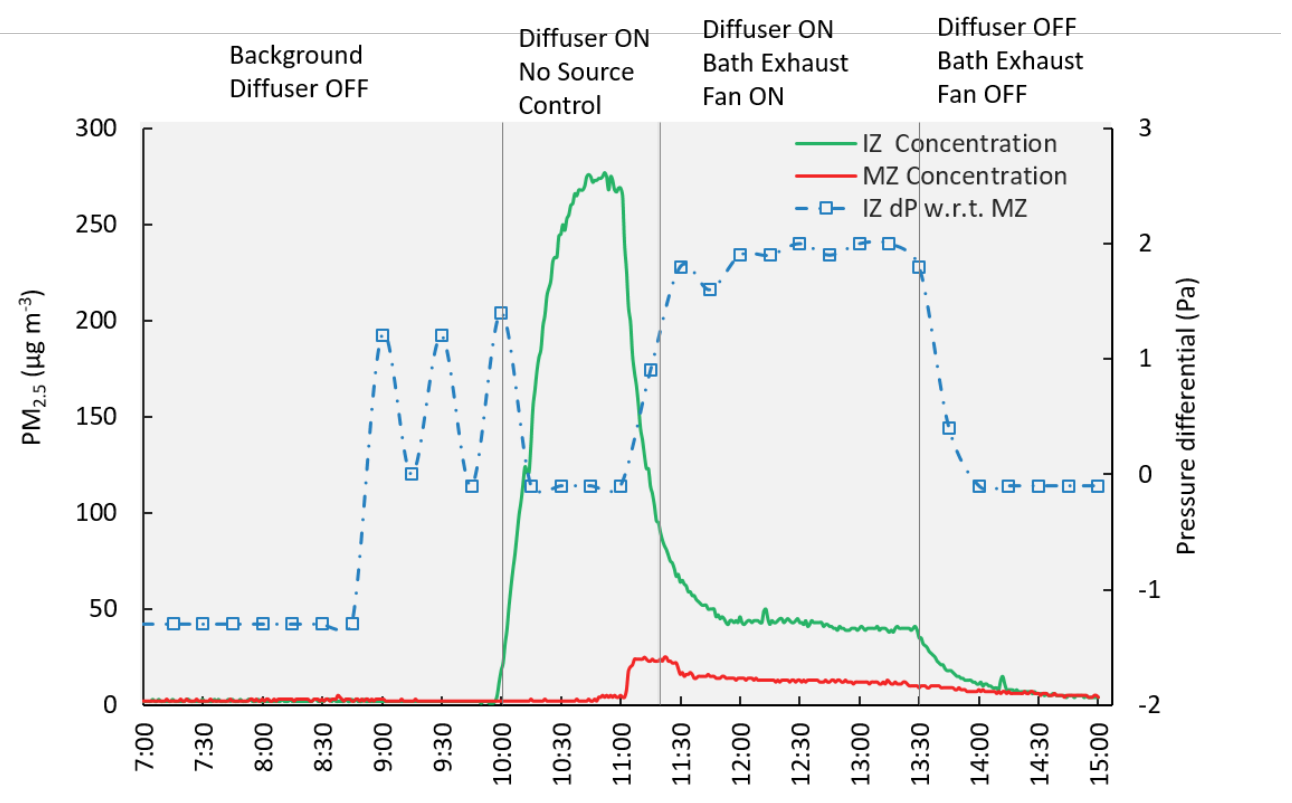

Figure 9. Time-series of $\mathrm{PM}_{2.5}$ for Case 11

\subsection{Special Cases}

\subsubsection{Effect of Opening/Closing Isolation Zone Door}

To test the effect of opening/closing the IZ door in diminishing containment potential and consequently allowing the transfer of air from the IZ to the MZ, we used the Case 5 configuration with occasional opening and closing of the IZ door. In this test, a total of three low-cost air quality monitors were placed in the MZ—one in the central MZ and the other two near the IZ door. Of these two monitors, one was placed near the IZ door undercut while the other one was placed at mid-height. A door state sensor was mounted on the IZ door, monitoring the duration of door closure and opening at 1-second intervals. The results from this test are shown in Figure 10(a) and (b). Both figures show similar data but for different times of the day, with varying duration of the door open/close.
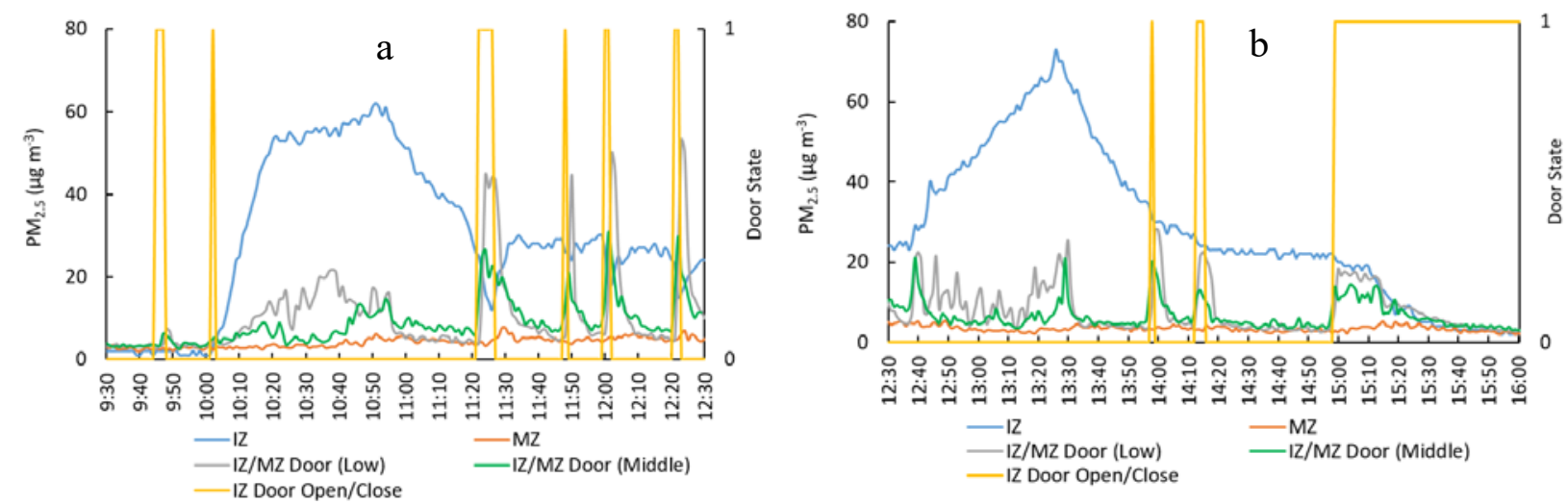

Figure 10. Effect of $I Z$ door opening/closing on $\mathrm{PM}_{2.5}$ transfer from $I Z$ to $M Z$. The primary vertical axis denotes $\mathrm{PM}_{2.5}$ concentrations measured at various locations and the secondary vertical axis denotes the state of the door $(1=$ open; 0 = closed $)$. 
Lab Home Testing of Residential Isolation Space Control to Minimize Infectious Disease Transmission in Existing Single-Family Homes

Overall, as can be seen in Figure 10, the $\mathrm{PM}_{2.5}$ concentrations in the $\mathrm{MZ}$ (orange line) remained substantially lower than the IZ concentration (blue line). Also, the concentrations measured at/near the door (by both monitors - gray and green lines) were mostly higher than that of the $\mathrm{MZ}$ concentration during the period of $\mathrm{PM}_{2.5}$ build-up for about an hour prior to beginning tests. One of these periods can be observed from 10:00-11:00 and another from 12:30-13:30. During these specific periods, all HVAC was off and the IZ door was closed to enable the $\mathrm{PM}_{2.5}$ to build-up concentration in the IZ. At the end of these periods, the bath exhaust fan was turned on, thereby improving containment. Containment was improved as the exhaust fan created a pressure difference of $-2.5 \mathrm{~Pa}$ to $-3.0 \mathrm{~Pa}$ in the IZ w.r.t. MZ. Better containment is also observed as the $\mathrm{PM}_{2.5}$ concentration abruptly drops toward the same value in the central MZ. This finding suggests that the door undercut acts as a passage for air transfer, allowing limited transfer of $\mathrm{PM}_{2.5}$ from the IZ to $\mathrm{MZ}$ whenever the IZ w.r.t. MZ is near neutral pressure. However, most of these aerosols do not find their way to the central area of the $\mathrm{MZ}$, as evident by little or no change in the simultaneously measured $\mathrm{MZ}$ concentrations.

Opening the IZ door resulted in a transient increase in $\mathrm{PM}_{2.5}$ concentrations, as indicated by the monitors placed near the door. The duration of this increase in concentrations is consistent with the duration of the door opening (Figure 10). It should be noted that while the door was left open, concentrations measured at or near the door undercut were higher than the measured concentrations at mid-height at the door. Measurements of the $\mathrm{SF}_{6}$ tracer gas at top, middle, and bottom door opening height also found the concentration increased moving from top to bottom. This could be explained by the temperature differential between zones, where colder dense IZ air readily moved into the $\mathrm{MZ}$ as less dense $\mathrm{MZ}$ air circulated into IZ more toward the top. For example, during 10:00-11:00 when the IZ exhaust fan was turned off, the average condition in the $\mathrm{MZ}$ was $66.9^{\circ} \mathrm{F}$ and $46.6 \% \mathrm{RH}\left(0.0751 \mathrm{lb} \mathrm{ft}^{-3}\right)$, and $63.7^{\circ} \mathrm{F}$ and $50.2 \% \mathrm{RH}\left(0.0751 \mathrm{lb} \mathrm{ft}^{-3}\right)$ in the IZ. While the temperature differentials are not very large, the measured conditions show that the IZ air was denser than the MZ air on average. The measured conditions were representative of each zone and were not taken at the doorway.

Overall, the results from this case suggest that leaving the IZ door open for several seconds to several minutes did not affect increasing the MZ concentrations.

\subsubsection{Effect of Using Kitchen Range Hood in the Main Zone}

Under neutral or near-neutral pressure conditions in the IZ, the use of local exhaust ventilation could depressurize the $\mathrm{MZ}$, resulting in a transfer of contaminated air from IZ to MZ. An example of this scenario is illustrated in Figure 11. After the build-up pre-test period (14:0015:28), a DuctBlaster simulating kitchen range hood operation with an exhaust flow of 100 CFM was activated for 30 minutes in the MZ kitchen area. This flow was selected based on the ASHRAE 62.2 requirement for local exhaust ventilation, which includes intermittent use of kitchen range hood in residential homes. During the simulated range hood operation period (15:29-16:02), the mean $\mathrm{MZ} \mathrm{PM}_{2.5}$ concentration increased to $6.4 \mu \mathrm{g} \mathrm{m}^{-3}$ from the mean concentration of $3.3 \mu \mathrm{g} \mathrm{m}^{-3}(14: 00-15: 28)$ just before the simulated hood operation. The mean 
Lab Home Testing of Residential Isolation Space Control to Minimize Infectious Disease Transmission in Existing Single-Family Homes

outdoor $\mathrm{PM}_{2.5}$ concentration during range hood operation was $4.1 \mu \mathrm{g} \mathrm{m}^{-3}$, suggesting that the increase in concentration in the MZ was primarily due to transfer of air from IZ to MZ. This example demonstrates that the use of local exhaust ventilation such as kitchen range hood or bathroom exhaust fan in the $\mathrm{MZ}$ could result in slight positive pressurization in the IZ as can be seen in Figure 11. Overall, the use of local exhaust ventilation in the MZ (under neutral/nearneutral IZ pressure differential conditions) could allow the transfer of fine particles $(<2.5 \mu \mathrm{m})$ from IZ to $\mathrm{MZ}$. However, if the outdoor $\mathrm{PM}_{2.5}$ concentrations are substantially higher than those observed during this study $\left(4-8 \mu \mathrm{g} \mathrm{m}^{-3}\right)$, make-up air from the outside could impact concentration levels in the MZ. In Figure 11, the large spike in the MZ beginning at about 17:15 was simply due to opening the door. The diffuser was turned off at the same time.

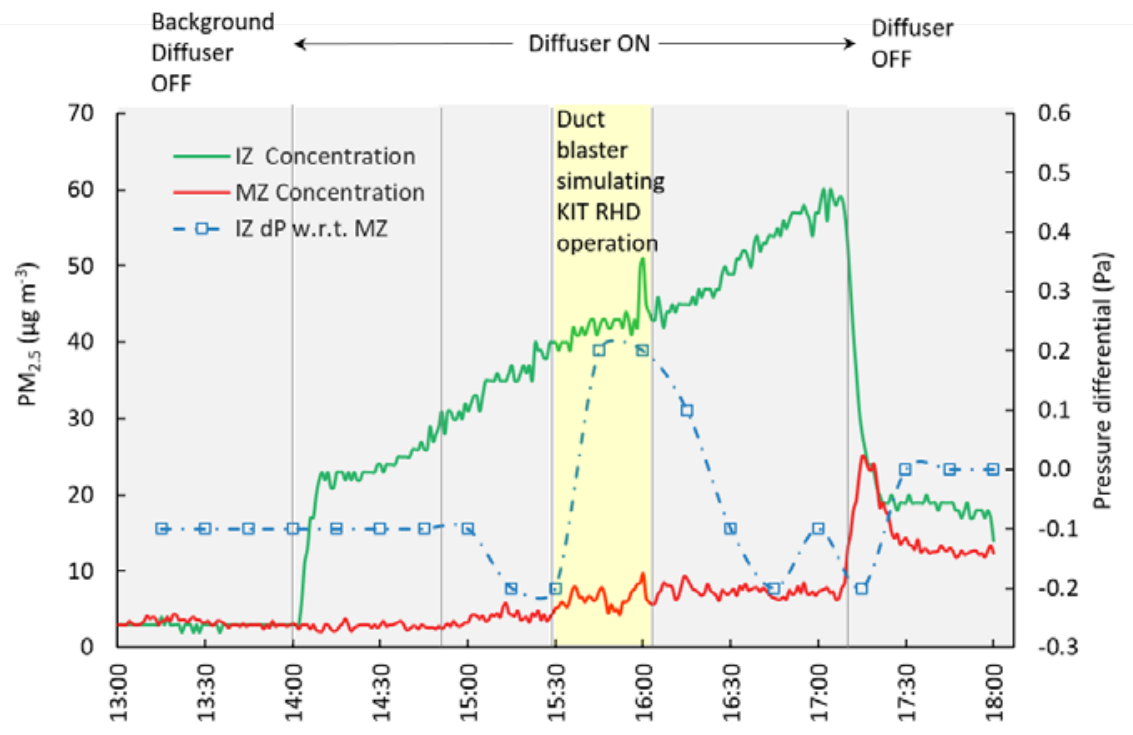

Figure 11. Effect of simulated kitchen range hood use in $\mathrm{PM}_{2.5}$ concentrations 


\section{Recommendations for Strong Isolation Zone Containment}

Infectious diseases can be transferred from person to person through various means of direct or indirect contact, and the easiest means of transmission may vary among different diseases. Direct contact transmits through touching another infectious person or infected surface. Indirect contact can transmit by inhalation of an airborne pathogen. Taking appropriate measures to address all transmission methods can lead to fuller protection. This research focused solely on ways to limit airborne transmission. Following is a summary of considerations from this project regarding efforts that can help limit exposure by creating an IZ:

- Use recommended personal protective equipment and cleaning practices.

- Locate an infectious person in a room with a closeable door. Placing them in a master bedroom with direct access to a bathroom will help limit exposure if there is a second bathroom available to healthy occupants in the home.

- Air pathways between the IZ and MZ should be sealed. The IZ door should remain closed at all times, except for occasional opening/closing as would be needed to tend to an ill person. All heating and cooling supply air grilles should be sealed off in the IZ.

- The IZ should be kept at a lower air pressure than the MZ. This can be accomplished by placing a window fan in the IZ window arranged to blow air from the IZ to outdoors. A $\$ 32$ window fan bought online for this project arrived within days and offered the most economic isolation control. This may also be done using a master bathroom exhaust fan with at least 100 CFM airflow. Many older existing exhausts are likely to produce inadequate containment, but would be better than using no other exhaust method.

- Although it is expected that containment is only needed for a short-term period of less than a month, situations requiring longer-term containment should ensure potential for moisture-related durability concerns is minimized during humid weather. In such cases, space cooling set points should not be set below the outdoor air dew point. This is especially important in homes with vapor-impermeable wall and/or floor coverings, such as vinyl wallpaper. Sealing off IZ supply grilles may result in uncomfortable conditions for the isolated person, so a room space heater or room air conditioner may be needed. An electric space heater and room air conditioner could cost $\$ 75$ and $\$ 300-\$ 600$, respectively.

- A portable room air conditioner with around 7,000 Btu/h output that exhausts air outdoors can provide cooling and help provide adequate negative IZ pressure with respect to $\mathrm{MZ}$ when it is operating, but containment ends whenever the unit cycles off unless another source of IZ exhaust is also used.

- Achieving adequate depressurization by opening windows is unpredictable because containment can be intermittent depending upon wind speed and direction. 
Lab Home Testing of Residential Isolation Space Control to Minimize Infectious Disease Transmission in Existing Single-Family Homes

\section{References}

Allen, J.G. and Marr, L.C. 2020. "Recognizing and controlling airborne transmission of SARSCoV-2 in indoor environments." Indoor air, 30(4), p.557.

Amoatey, P., Omidvarborna, H., Baawain, M.S. and Al-Mamun, A. 2020. "Impact of building ventilation systems and habitual indoor incense burning on SARS-CoV-2 virus transmissions in Middle Eastern countries." Science of The Total Environment, 733, p.139356.

ASHRAE Standard 170. 2013. "Ventilation for Health Care Facilities.” Atlanta, GA.

ASHRAE. 2020. "Position Document on Infectious Aerosols.” Atlanta, GA.

Asadi, N.B., Wexler, A.S. and Ristenpart, W.D., 2020. "The coronavirus pandemic and aerosols: Does COVID-19 transmit via expiratory particles?" Aerosol Science and Technology, 54:6, 635638.

Chia, P.Y., Coleman, K.K., Tan, Y.K., Ong, S.W.X., Gum, M., Lau, S.K., Sutjipto, S., Lee, P.H., Young, B.E., Milton, D.K. and Gray, G.C. 2020. "Detection of air and surface contamination by severe acute respiratory syndrome coronavirus 2 (SARS-CoV-2) in hospital rooms of infected patients." MedRxiv.

Cummings, J., Moyer, N., and Tooley, J. 1990. Radon Pressure Differential Project; Phase IIInfiltration. Final Report FSEC-CR-370-90 Florida Solar Energy Center. p. 19.

Fehr, A.R. and Perlman, S. 2015. "Coronaviruses: an overview of their replication and pathogenesis.” Coronaviruses (pp. 1-23). Humana Press, New York, NY.

Garcia de Abajo, F.J., Hernández, R.J., Kaminer, I., Meyerhans, A., Rosell-Llompart, J. and Sanchez-Elsner, T. 2020. "Back to normal: an old physics route to reduce SARS-CoV-2 transmission in indoor spaces." ACS nano, 14(7), pp.7704-7713.

He, S. and Han, J. 2020. "Electrostatic fine particles emitted from laser printers as potential vectors for airborne transmission of COVID-19." Environmental Chemistry Letters, pp.1-8.

Khan, T.R. and Perlinger, J.A. 2017. "Evaluation of five dry particle deposition parameterizations for incorporation into atmospheric transport models." Geoscientific Model Development, 10(10), p.3861.

Lednicky, J.A., Lauzard, M., Fan, Z.H., Jutla, A., Tilly, T.B., Gangwar, M., Usmani, M., Shankar, S.N., Mohamed, K., Eiguren-Fernandez, A. and Stephenson, C.J., 2020. "Viable SARS-CoV-2 in the air of a hospital room with COVID-19 patients." International Journal of Infectious Diseases, 100, pp. 476-482.

Liu, Y., Ning, Z., Chen, Y., Guo, M., Liu, Y., Gali, N.K., Sun, L., Duan, Y., Cai, J., Westerdahl, D. and Liu, X. 2020. "Aerodynamic analysis of SARS-CoV-2 in two Wuhan hospitals." Nature, 582(7813), pp. 557-560.

Mahabee-Gittens, E.M., Merianos, A.L. and Matt, G.E. 2020. Letter to the editor regarding: "an imperative need for research on the role of environmental factors in transmission of novel coronavirus (COVID-19)"- - secondhand and thirdhand smoke as potential sources of COVID19. Environmental science \& technology, 54(9), pp. 5309-5310. 
Lab Home Testing of Residential Isolation Space Control to Minimize Infectious Disease Transmission in Existing Single-Family Homes

Miller, S.L., Clements, N., Elliott, S.A., Subhash, S.S., Eagan, A. and Radonovich, L.J. 2017. "Implementing a negative-pressure isolation ward for a surge in airborne infectious patients." American journal of infection control, 45(6), pp. 652-659.

Miller, S.L., Nazaroff, W.W., Jimenez, J.L., Boerstra, A., Buonanno, G., Dancer, S.J., Kurnitski, J., Marr, L.C., Morawska, L. and Noakes, C. 2020. "Transmission of SARS-CoV-2 by inhalation of respiratory aerosol in the Skagit Valley Chorale superspreading event." Indoor air.

Morawska, L. and Cao, J. 2020. "Airborne transmission of SARS-CoV-2: The world should face the reality." Environment international, 139, p. 105730.

Morawska, L., Tang, J.W., Bahnfleth, W., Bluyssen, P.M., Boerstra, A., Buonanno, G., Cao, J., Dancer, S., Floto, A., Franchimon, F. and Haworth, C. 2020. "How can airborne transmission of COVID-19 indoors be minimised?" Environment international, 142, p. 105832.

Moyer, N., Beal, D., Chasar, D., McIlvaine, J., Withers, C., and Chandra, S. 2001. "Moisture Problems in Manufactured Housing: Probable Cause and Cures." ASHRAE IAQ 2001 Conference Proceedings. https://publications.energyresearch.ucf.edu/wpcontent/uploads/2018/06/FSEC-GP-212-01.pdf. Accessed Apr. 9, 2021.

Prather, K.A., Wang, C.C. and Schooley, R.T. 2020a. "Reducing transmission of SARS-CoV-2." Science, 368(6498), pp. 1422-1424.

Prather, K.A., Marr, L.C., Schooley, R.T., McDiarmid, M.A., Wilson, M.E. and Milton, D.K. 2020b. "Airborne transmission of SARS-CoV-2." Science, 370(6514), pp. 303-304.

Qu, G., Li, X., Hu, L. and Jiang, G. 2020. “An imperative need for research on the role of environmental factors in transmission of novel coronavirus (COVID-19)." Environ. Sci. Technol. 2020, 54, 7, 3730-3732.

Riccò, M., Ranzieri, S., Balzarini, F., Bragazzi, N.L. and Corradi, M. 2020. "SARS-CoV-2 infection and air pollutants: Correlation or causation?" The Science of the total environment, 734, p.139489.

Swami, M., Cummings, J., Sen Sharma, R., Withers, C., and Basarkar, M. 2006. Florida Building Code-Enhance Florida's Building to Next-Generation Energy \& Mechanical Codes and Enrich Compliance. Final Report FSEC-CR-1678-06 Florida Solar Energy Center. pp. 1822.

Tellier, R., 2006. "Review of aerosol transmission of influenza A virus.” Emerging infectious diseases, 12(11), p.1657.

Tung, N.T., Cheng, P.C., Chi, K.H., Hsiao, T.C., Jones, T., BéruBé, K., Ho, K.F. and Chuang, H.C. 2021. "Particulate matter and SARS-CoV-2: a possible model of COVID-19 transmission." Science of The Total Environment, 750, p. 141532.

WHO Guidelines. 2009. "Natural ventilation for infection control in health-care settings." https://www.who.int/water sanitation health/publications/natural ventilation/en/. Accessed Jan. 30, 2021. 


\section{Appendix A. Project Photos}

These photos show equipment used in this project that may be useful in creating an isolation zone (IZ) in a residence with $-2.5 \mathrm{~Pa}$ or more pressure with reference to the main zone (MZ). The window fan used was purchased new for $\$ 32$ and was the most cost-effective method in creating adequate negative pressure in the IZ. This happened to be a twin fan design, but a single portable fan that moves about 300 CFM airflow would work just as well. Figure A1 shows the window fan installed in the IZ (master bedroom) exhausting air to outdoors. Figure A2 shows the same fan as installed in the $M Z$ to bring outdoor air into the MZ. This pressurizes the MZ resulting in a lesser pressure in the closed-off IZ with reference to MZ, which helps with containment.

The portable room air conditioner can help maintain comfortable IZ conditions in a closed-off IZ and also helps depressurize the IZ through the exhaust to outdoors while it is cooling. Figure A3 shows the room air-conditioning unit from indoors, and Figure A4 shows the unit exhaust in exterior IZ window from outdoors.

The bathroom exhaust used within the IZ (master bedroom bathroom) is shown in Figure A5, which also shows one of the sealed-off supply grilles. Figures A6-A9 show some of the monitoring equipment used.

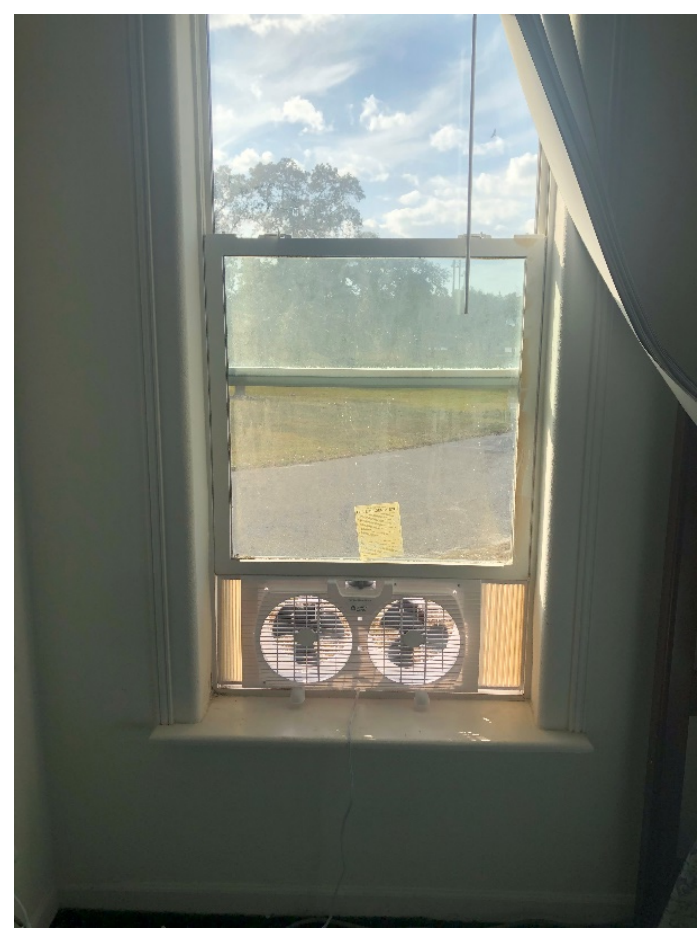

Figure A1. Window fan installed in the IZ exhausting air to outdoors

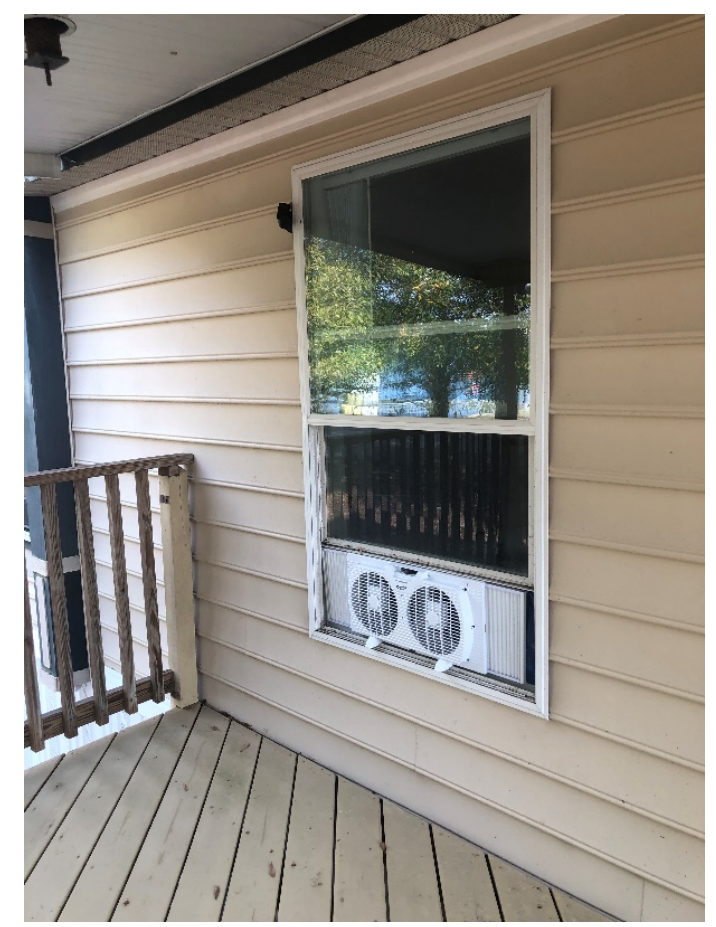

Figure A2. Window fan installed in $\mathrm{MZ}$ providing outdoor air into home 
Lab Home Testing of Residential Isolation Space Control to Minimize Infectious Disease Transmission in Existing Single-Family Homes

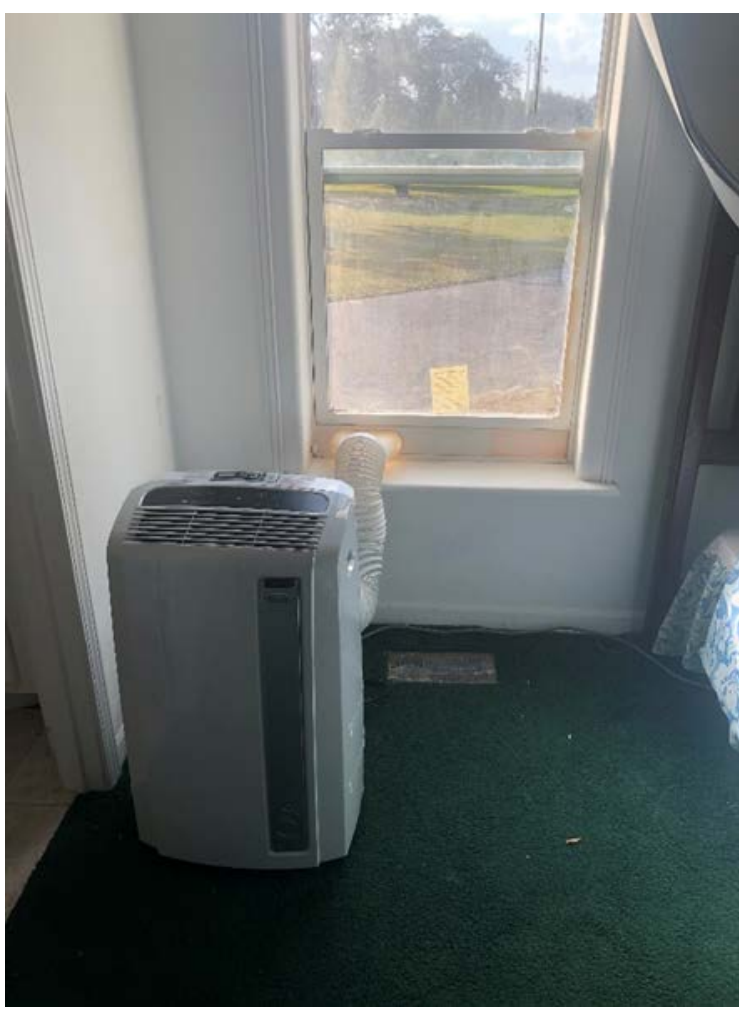

Figure A3. Portable air conditioner in IZ with unit exhaust through window

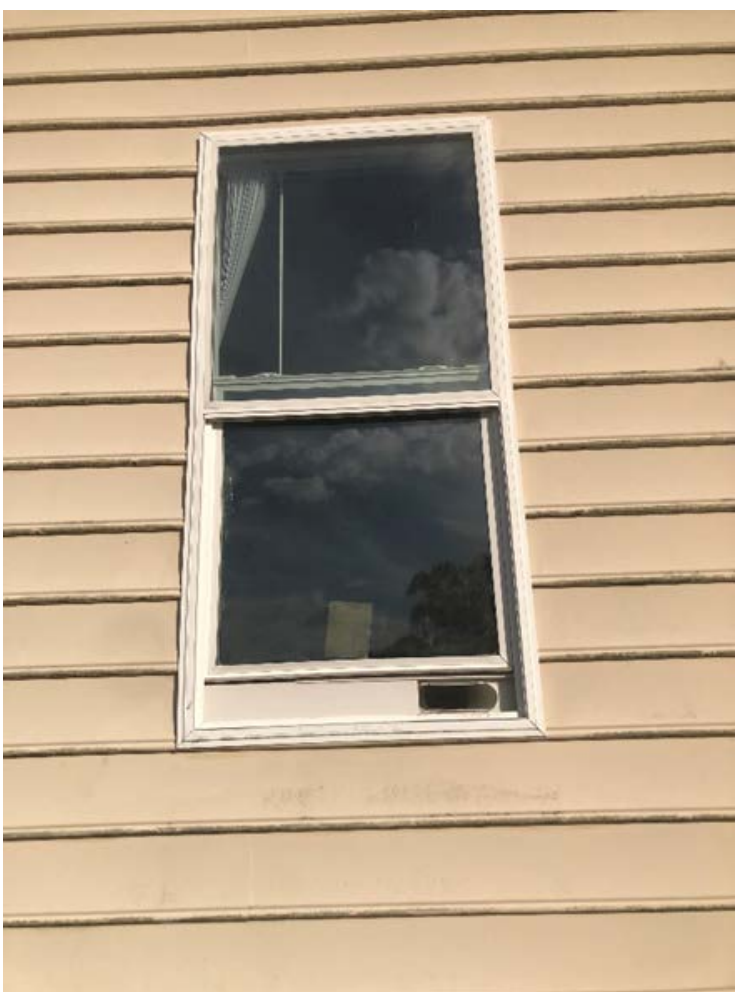

Figure A4. Room air conditioner exhaust discharge view from outdoors

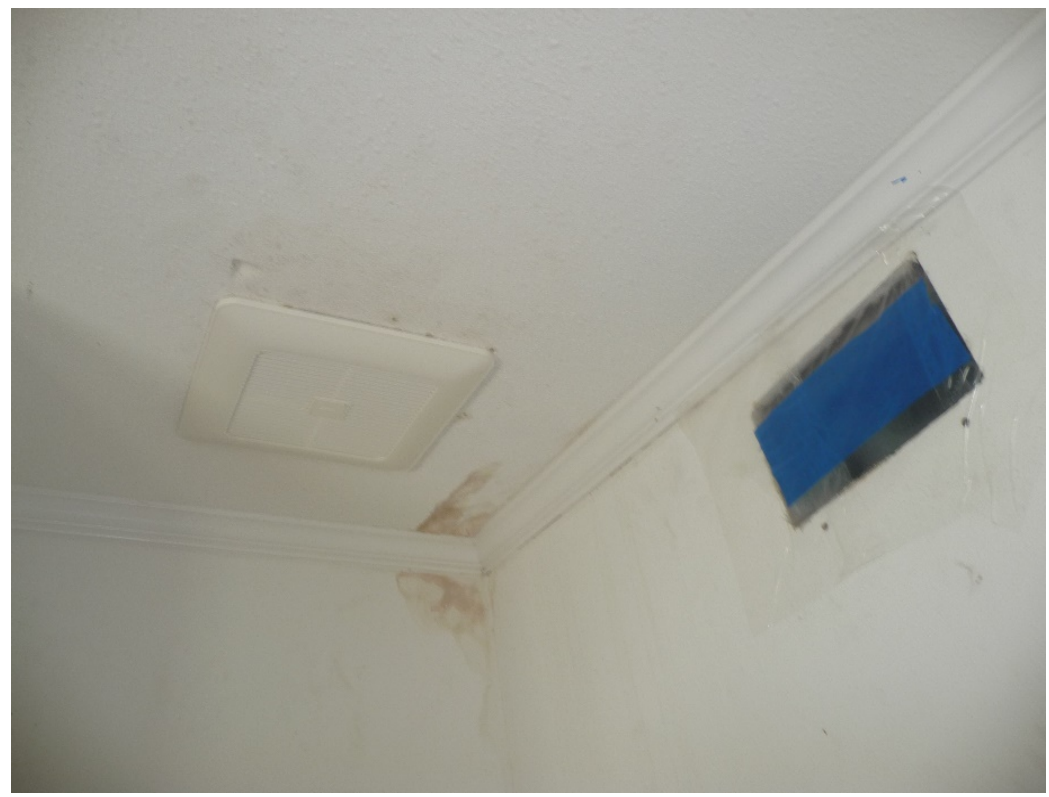

Figure A5. Bathroom exhaust fan in IZ shown next to a sealed off supply grille 
Lab Home Testing of Residential Isolation Space Control to Minimize Infectious Disease Transmission in Existing Single-Family Homes

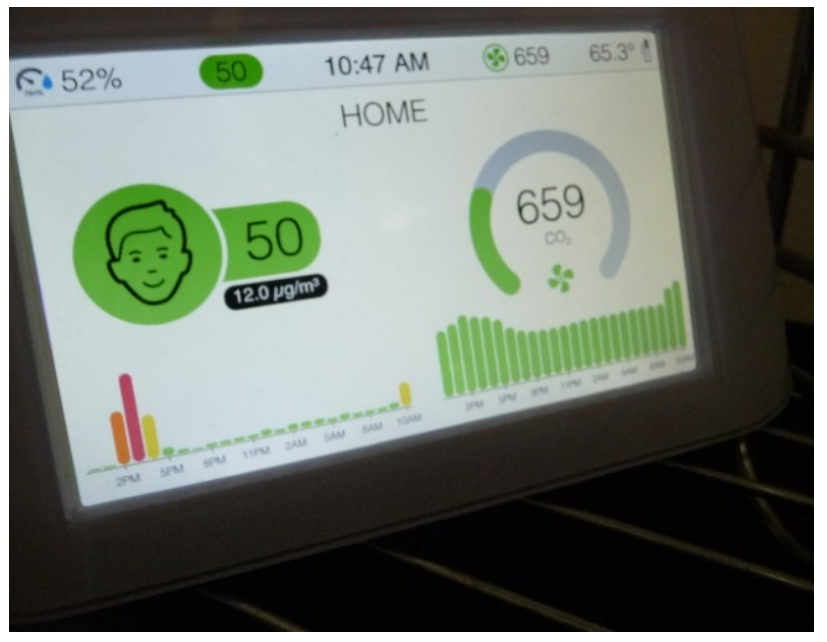

Figure A6. Screen of the Air Visual Pro PM2.5 sensor used in study

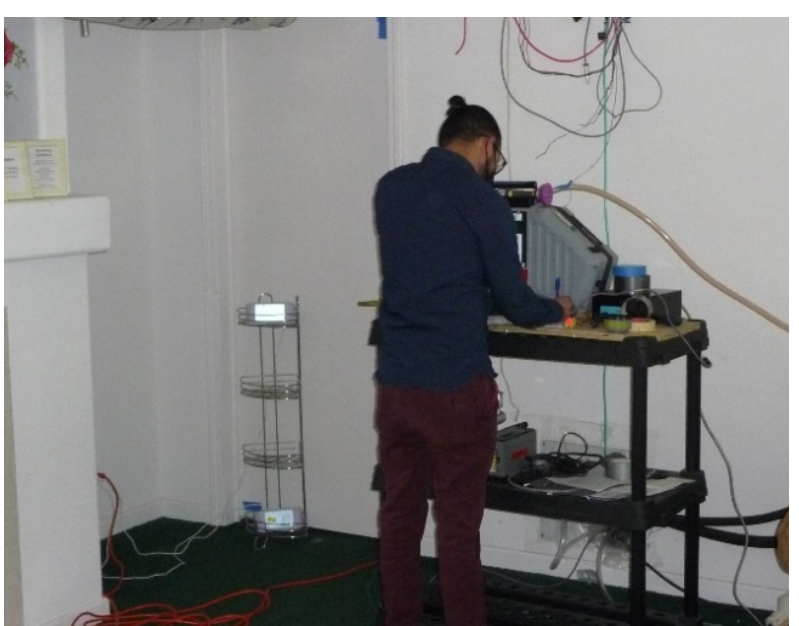

Figure A7. Taking tracer gas measurements with Miran Sapphire sulfur hexafluoride monitor and low-cost $\mathrm{PM}_{2.5}$ monitors (AVP) from the MZ, just outside of IZ closed door

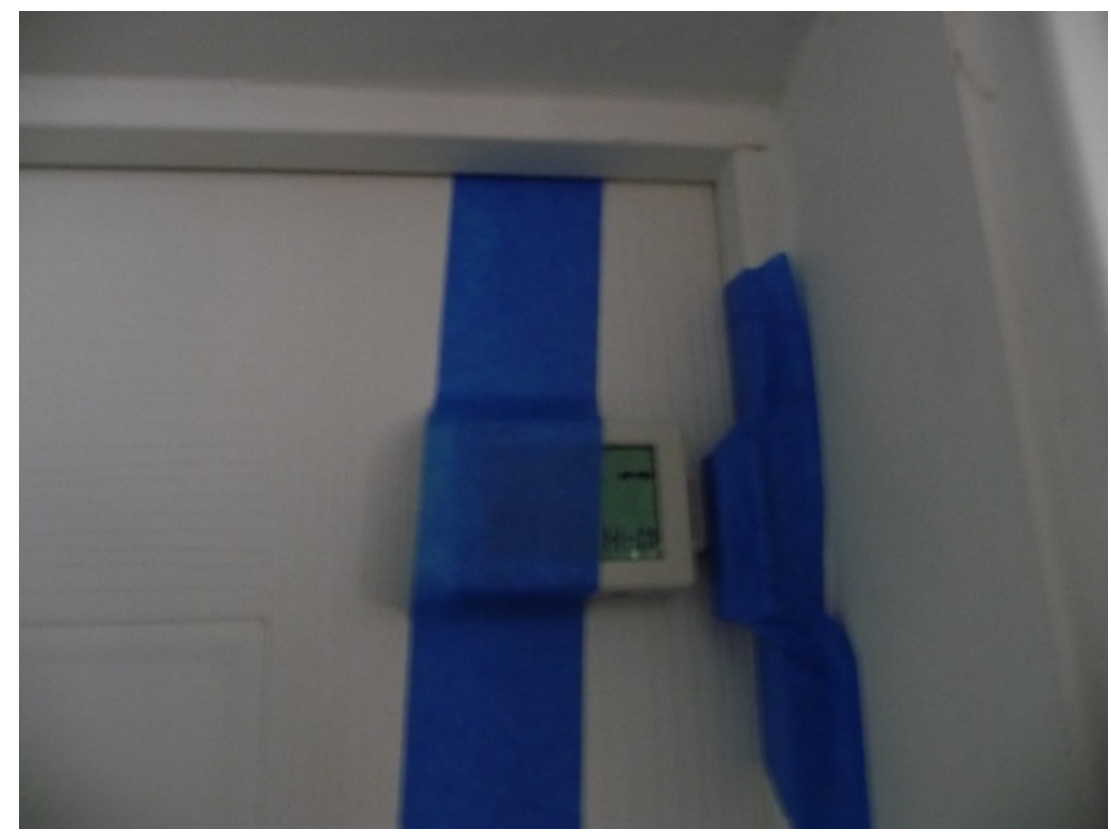

Figure A8. Door open/close sensor on IZ door 
Lab Home Testing of Residential Isolation Space Control to Minimize Infectious Disease Transmission in Existing Single-Family Homes
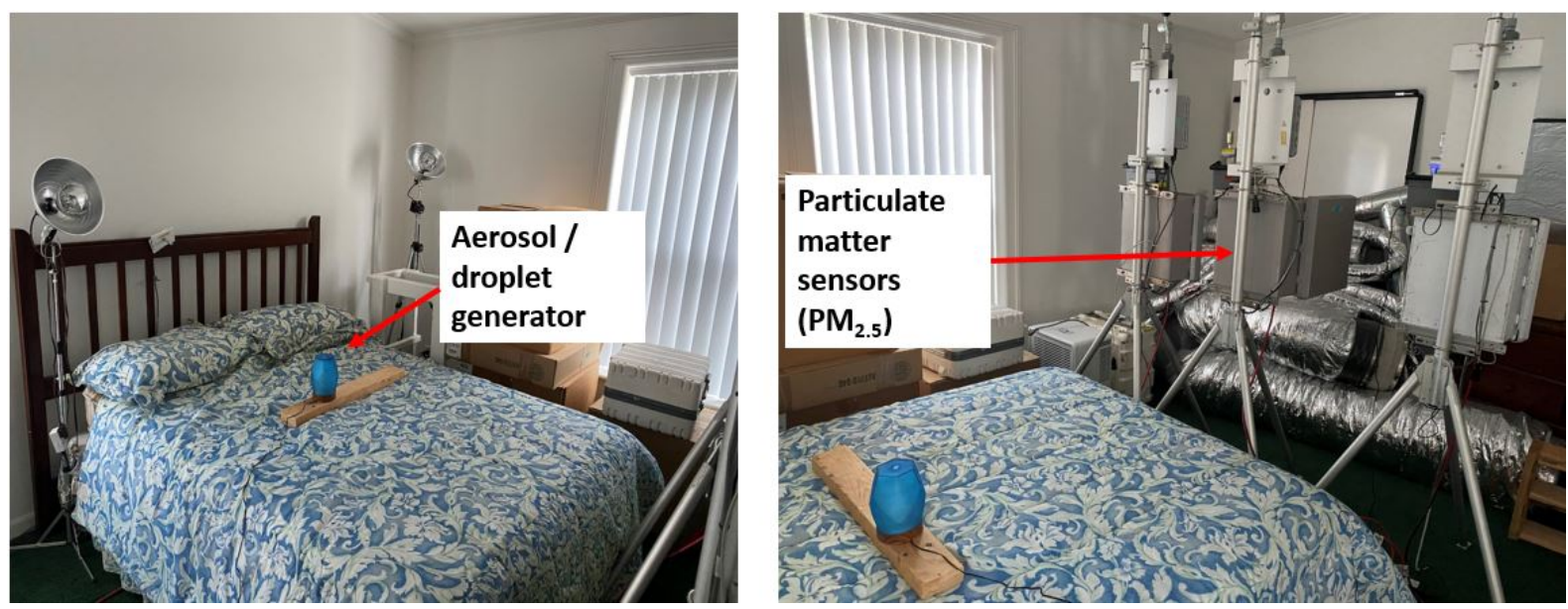

Figure A9. Diffuser and $\mathrm{PM}_{2.5}$ monitors inside the IZ 
